\title{
LEVEL II SCOUR ANALYSIS FOR BRIDGE 10 (GROTTH00240010) on TOWN HIGHWAY 24, crossing HEATH BROOK, GROTON, VERMONT
}

U.S. Geological Survey Open-File Report 98-288

Prepared in cooperation with

VERMONT AGENCY OF TRANSPORTATION and

FEDERAL HIGHWAY ADMINISTRATION

U.S. Department of the Interior U.S. Geological Survey

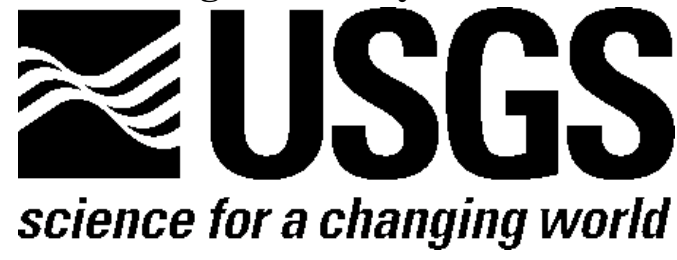




\section{LEVEL II SCOUR ANALYSIS FOR BRIDGE 10 (GROTTH00240010) on TOWN HIGHWAY 24, crossing HEATH BROOK, GROTON, VERMONT}

By LORA K. STRIKER AND ROBERT E. HAMMOND

U.S. Geological Survey Open-File Report 98-288

Prepared in cooperation with

VERMONT AGENCY OF TRANSPORTATION

and

FEDERAL HIGHWAY ADMINISTRATION 


\title{
U.S. DEPARTMENT OF THE INTERIOR BRUCE BABBITT, Secretary
}

\author{
U.S. GEOLOGICAL SURVEY
}

Thomas J. Casadevall, Acting Director

For additional information write to:

District Chief

U.S. Geological Survey 361 Commerce Way

Pembroke, NH 03275-3718
Copies of this report may be purchased from:

U.S. Geological Survey

Branch of Information Services

Open-File Reports Unit

Box 25286

Denver, CO 80225-0286 


\section{CONTENTS}

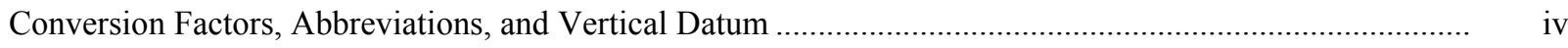

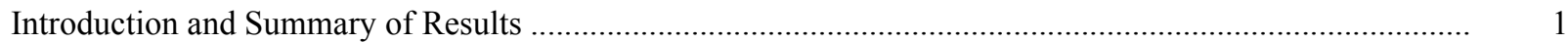

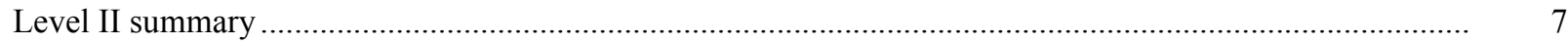

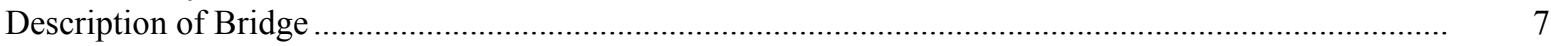

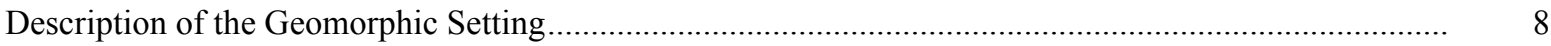

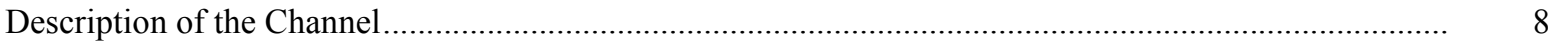

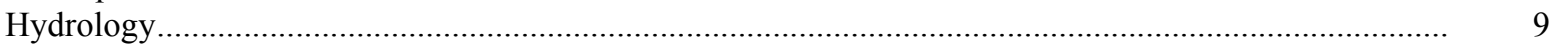

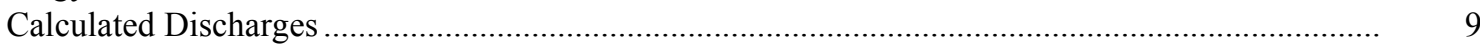

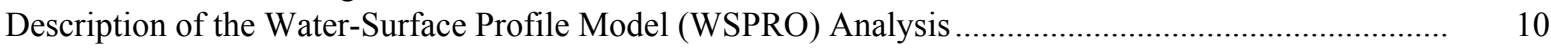

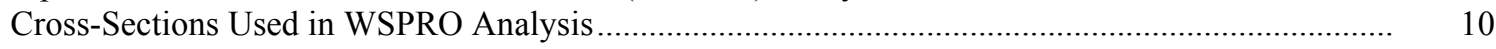

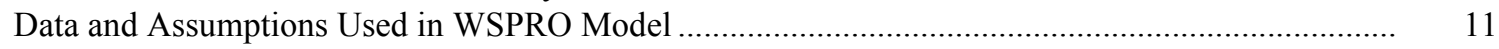

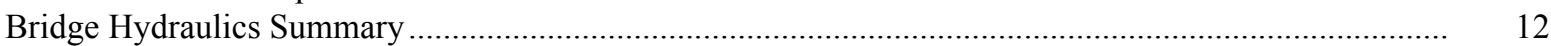

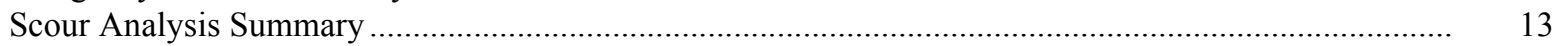

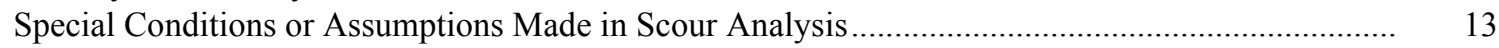

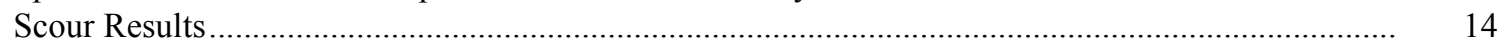

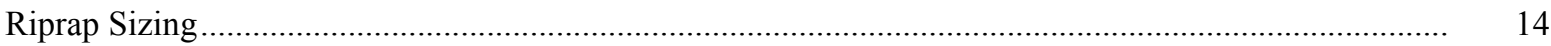

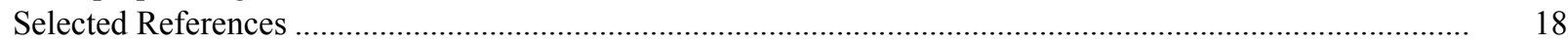

Appendices:

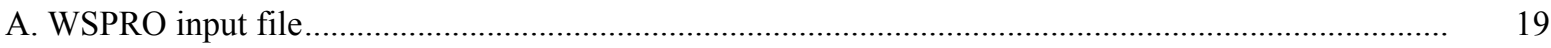

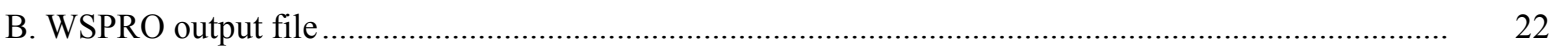

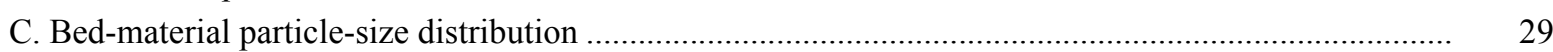

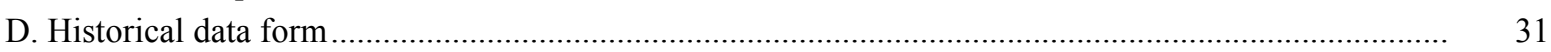

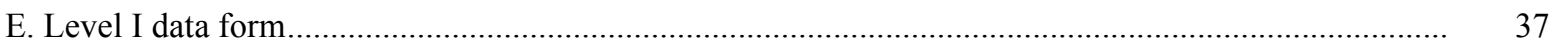

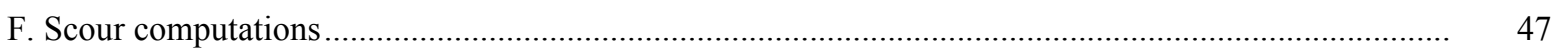

\section{FIGURES}

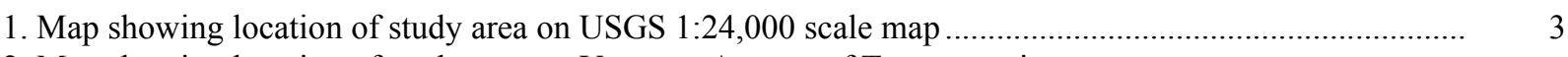

2. Map showing location of study area on Vermont Agency of Transportation town

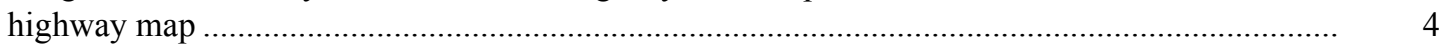

3. Structure GROTTH00240010 viewed from upstream (August 29, 1995).......................................... 5

4. Downstream channel viewed from structure GROTTH00240010 (August 29, 1995)............................ 5

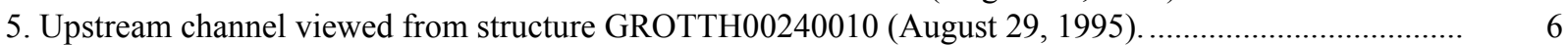

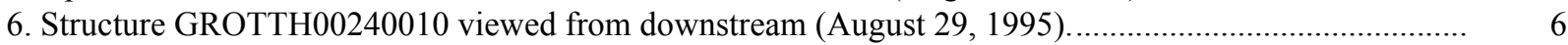

7. Water-surface profiles for the 100- and 500-year discharges at structure

GROTTH00240010 on Town Highway 24, crossing Heath Brook,

Groton, Vermont.

8. Scour elevations for the 100- and 500-year discharges at structure

GROTTH00240010 on Town Highway 24, crossing Heath Brook,

Groton, Vermont.

\section{TABLES}

1. Remaining footing/pile depth at abutments for the 100-year discharge at structure GROTTH00240010 on Town Highway 24, crossing Heath Brook,

Groton, Vermont

2. Remaining footing/pile depth at abutments for the 500-year discharge at structure

GROTTH00240010 on Town Highway 24, crossing Heath Brook,

Groton, Vermont 


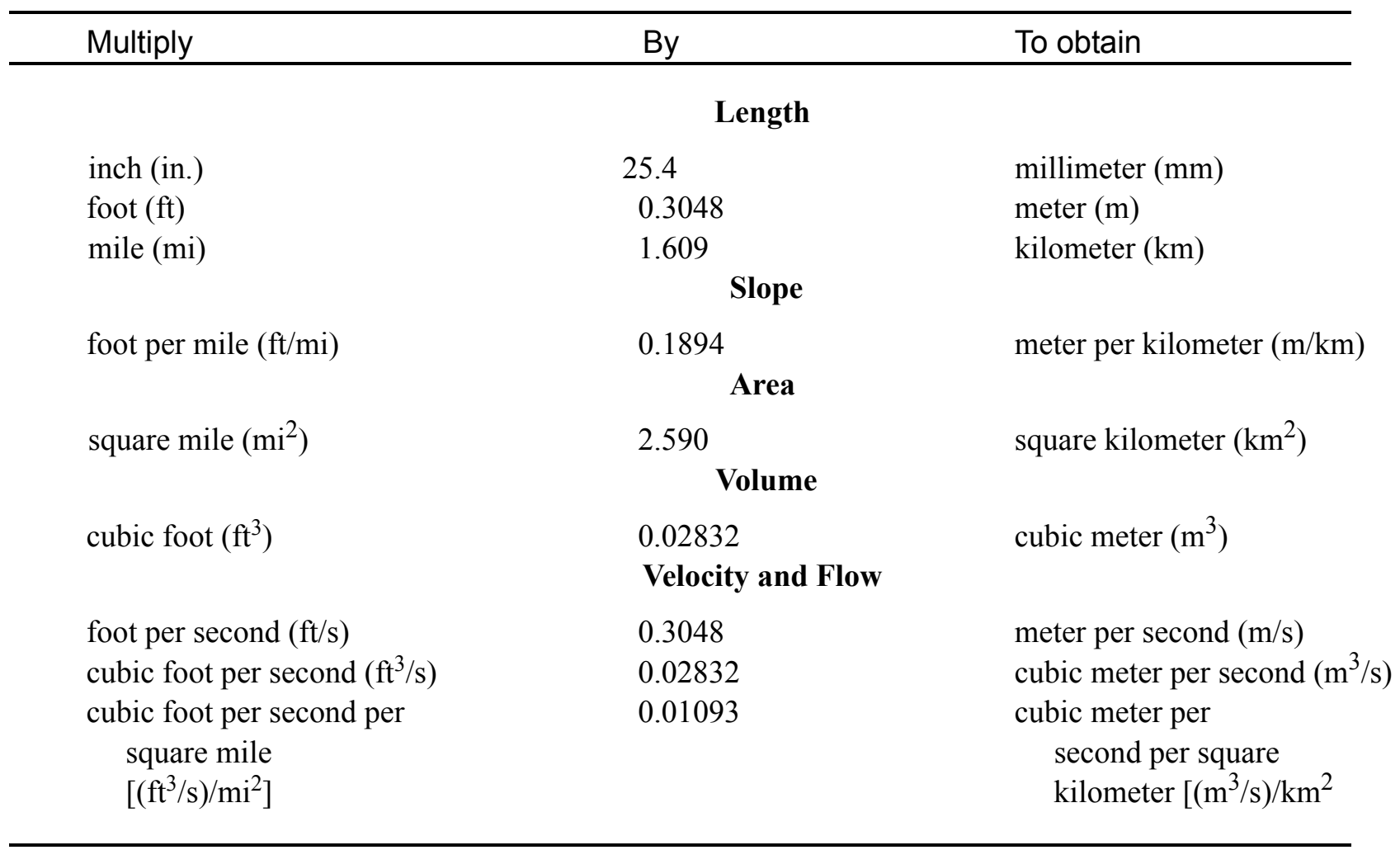

\section{OTHER ABBREVIATIONS}

$\begin{array}{lrlr}\mathrm{BF} & \text { bank full } & \text { LWW } & \text { left wingwall } \\ \mathrm{cfs} & \text { cubic feet per second } & \text { Max } & \text { maximum } \\ \mathrm{D}_{50} & \text { median diameter of bed material } & \text { MC } & \text { main channel } \\ \mathrm{DS} & \text { downstream } & \text { RAB } & \text { right abutment } \\ \mathrm{elev} & \text { elevation } & \text { RABUT } & \text { face of right abutment } \\ \mathrm{f} / \mathrm{p} & \text { flood plain } & \text { RB } & \text { right bank } \\ \mathrm{ft} & \text { square feet } & \text { ROB } & \text { right overbank } \\ \mathrm{ft} / \mathrm{ft} & \text { feet per foot } & \text { RWW } & \text { right wingwall } \\ \mathrm{FEMA} & \text { Federal Emergency Management Agency } & \text { TH } & \text { town highway } \\ \mathrm{FHWA} & \text { Federal Highway Administration } & \text { UB } & \text { under bridge } \\ \mathrm{JCT} & \text { junction } & \text { US } & \text { upstream } \\ \text { LAB } & \text { left abutment } & \text { USGS } & \text { United States Geological Survey } \\ \text { LABUT } & \text { face of left abutment } & \text { VTAOT } & \text { Vermont Agency of Transportation } \\ \text { LB } & \text { left bank } & \text { WSPRO } & \text { water-surface profile model } \\ \text { LOB } & \text { left overbank } & \text { yr } & \text { year }\end{array}$

In this report, the words "right" and "left" refer to directions that would be reported by an observer facing downstream. Sea level: In this report, "sea level" refers to the National Geodetic Vertical Datum of 1929-- a geodetic datum derived from a general adjustment of the first-order level nets of the United States and Canada, formerly called Sea Level Datum of 1929.

In the appendices, the above abbreviations may be combined. For example, USLB would represent upstream left bank. 


\title{
LEVEL II SCOUR ANALYSIS FOR BRIDGE 10 (GROTTH00240010) ON TOWN HIGHWAY 24, CROSSING HEATH BROOK, GROTON, VERMONT
}

\author{
By Lora K. Striker and Robert E. Hammond
}

\section{INTRODUCTION AND SUMMARY OF RESULTS}

This report provides the results of a detailed Level II analysis of scour potential at structure GROTTH00240010 on Town Highway 24 crossing Heath Brook, Groton, Vermont (figures $1-8)$. A Level II study is a basic engineering analysis of the site, including a quantitative analysis of stream stability and scour (FHWA, 1993). Results of a Level I scour investigation also are included in appendix $\mathrm{E}$ of this report. A Level I investigation provides a qualitative geomorphic characterization of the study site. Information on the bridge, gleaned from Vermont Agency of Transportation (VTAOT) files, was compiled prior to conducting Level I and Level II analyses and is found in appendix D.

The site is in the New England Upland section of the New England physiographic province in east-central Vermont. The $5.6-\mathrm{mi}^{2}$ drainage area is in a predominantly rural and forested basin. In the vicinity of the study site, the surface cover is predominantly pasture.

In the study area, the Heath Brook has an incised, straight channel with a slope of approximately $0.01 \mathrm{ft} / \mathrm{ft}$, an average channel top width of $53 \mathrm{ft}$ and an average bank height of $9 \mathrm{ft}$. The channel bed material ranges from gravel to boulder with a median grain size $\left(\mathrm{D}_{50}\right)$ of $77.5 \mathrm{~mm}(0.254 \mathrm{ft})$. The geomorphic assessment at the time of the Level I and Level II site visit on August 29, 1995, indicated that the reach was stable.

The Town Highway 24 crossing of the Heath Brook is a $30-\mathrm{ft}-$ long, two-lane bridge consisting of one 27-foot concrete span (Vermont Agency of Transportation, written communication, March 17, 1995). The opening length of the structure parallel to the bridge face is $24.9 \mathrm{ft}$.The bridge is supported by vertical, concrete abutments with wingwalls. The channel is skewed approximately 30 degrees to the opening while the computed openingskew-to-roadway is 30 degrees.

A scour hole $3.0 \mathrm{ft}$ deeper than the mean thalweg depth was observed in mid-channel underneath the bridge during the Level I assessment. Scour protection measures at the site were type-3 stone fill (less than 48 inches diameter) along the left bank upstream, and type2 stone fill (less than 36 inches diameter) along the right bank upstream, the left and right bank downstream, along the entire base length of the left and right abutments and upstream and downstream wingwalls. Additional details describing conditions at the site are included in the Level II Summary and appendices D and E. 
Scour depths and recommended rock rip-rap sizes were computed using the general guidelines described in Hydraulic Engineering Circular 18 (Richardson and Davis, 1995) for the 100- and 500-year discharges. In addition, the incipient roadway-overtopping discharge is determined and analyzed as another potential worst-case scour scenario. Total scour at a highway crossing is comprised of three components: 1) long-term streambed degradation; 2) contraction scour (due to accelerated flow caused by a reduction in flow area at a bridge) and; 3 ) local scour (caused by accelerated flow around piers and abutments). Total scour is the sum of the three components. Equations are available to compute depths for contraction and local scour and a summary of the results of these computations follows.

Contraction scour for all modelled flows ranged from 0.0 to $1.1 \mathrm{ft}$. The worst-case contraction scour occurred at the incipient roadway-overtopping discharge which was less than the 100-year discharge. Abutment scour ranged from 7.1 to $8.1 \mathrm{ft}$ at the left abutment and 4.4 to 5.3 at the right abutment. The worst-case abutment scour occurred at the 500-year discharge at the left abutment and at the incipient roadway-overtopping discharge for the right abutment. Additional information on scour depths and depths to armoring are included in the section titled "Scour Results". Scoured-streambed elevations, based on the calculated scour depths, are presented in tables 1 and 2. A cross-section of the scour computed at the bridge is presented in figure 8 . Scour depths were calculated assuming an infinite depth of erosive material and a homogeneous particle-size distribution.

It is generally accepted that the Froehlich equation (abutment scour) gives "excessively conservative estimates of scour depths" (Richardson and Davis, 1995, p. 47). Usually, computed scour depths are evaluated in combination with other information including (but not limited to) historical performance during flood events, the geomorphic stability assessment, existing scour protection measures, and the results of the hydraulic analyses. Therefore, scour depths adopted by VTAOT may differ from the computed values documented herein. 


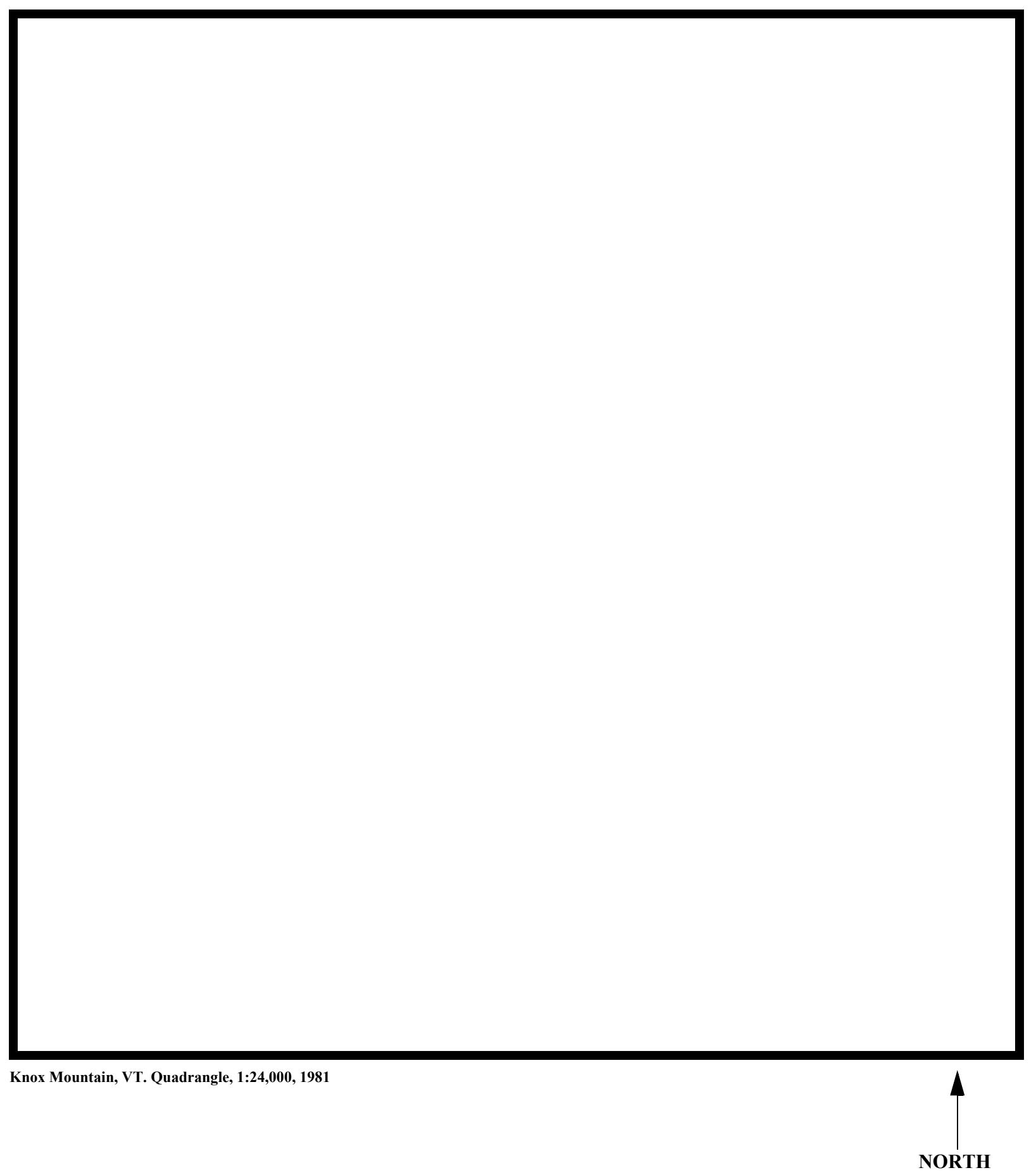

Figure 1. Location of study area on USGS 1:24,000 scale map. 
Figure 2. Location of study area on Vermont Agency of Transportation town highway map. 

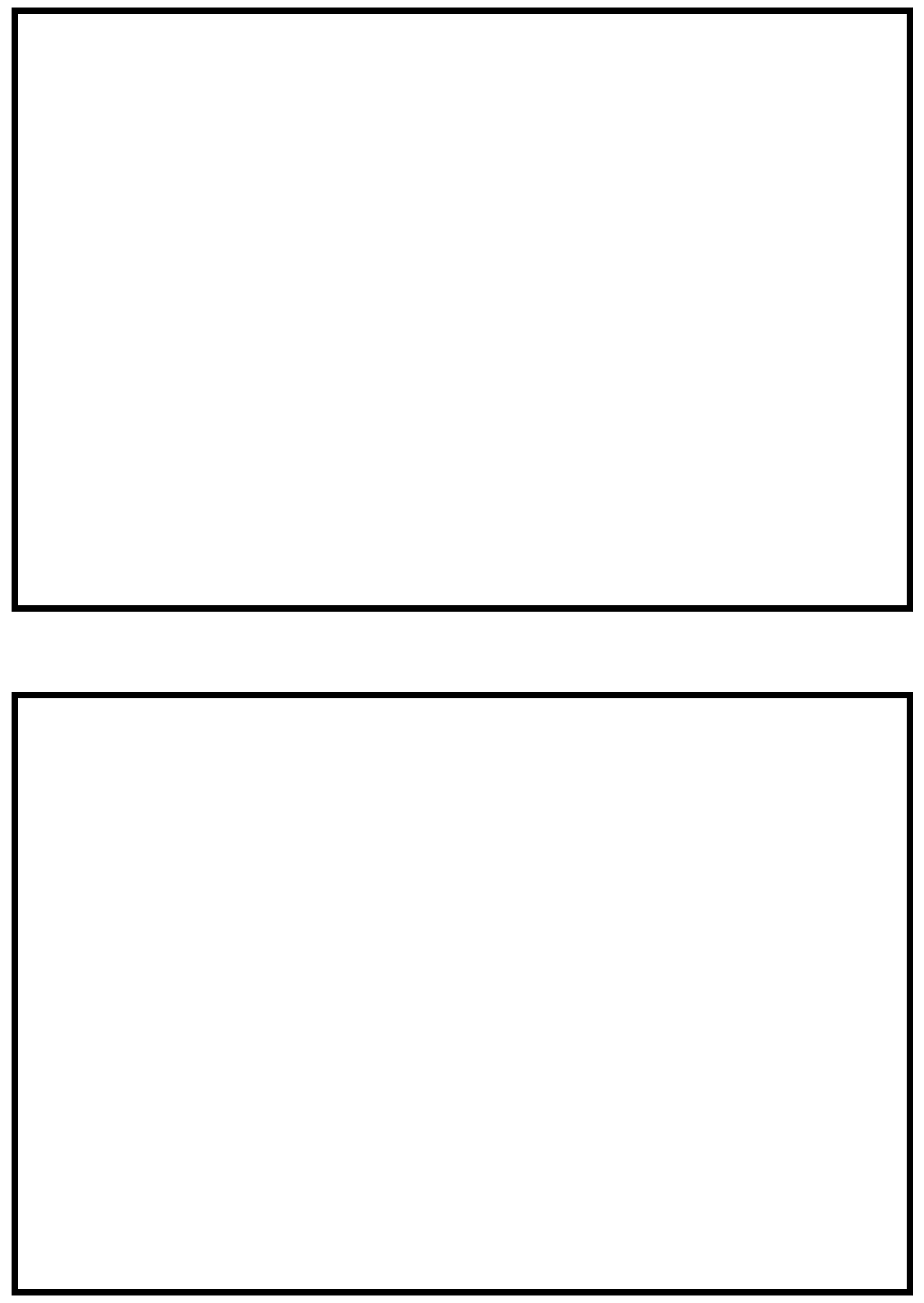

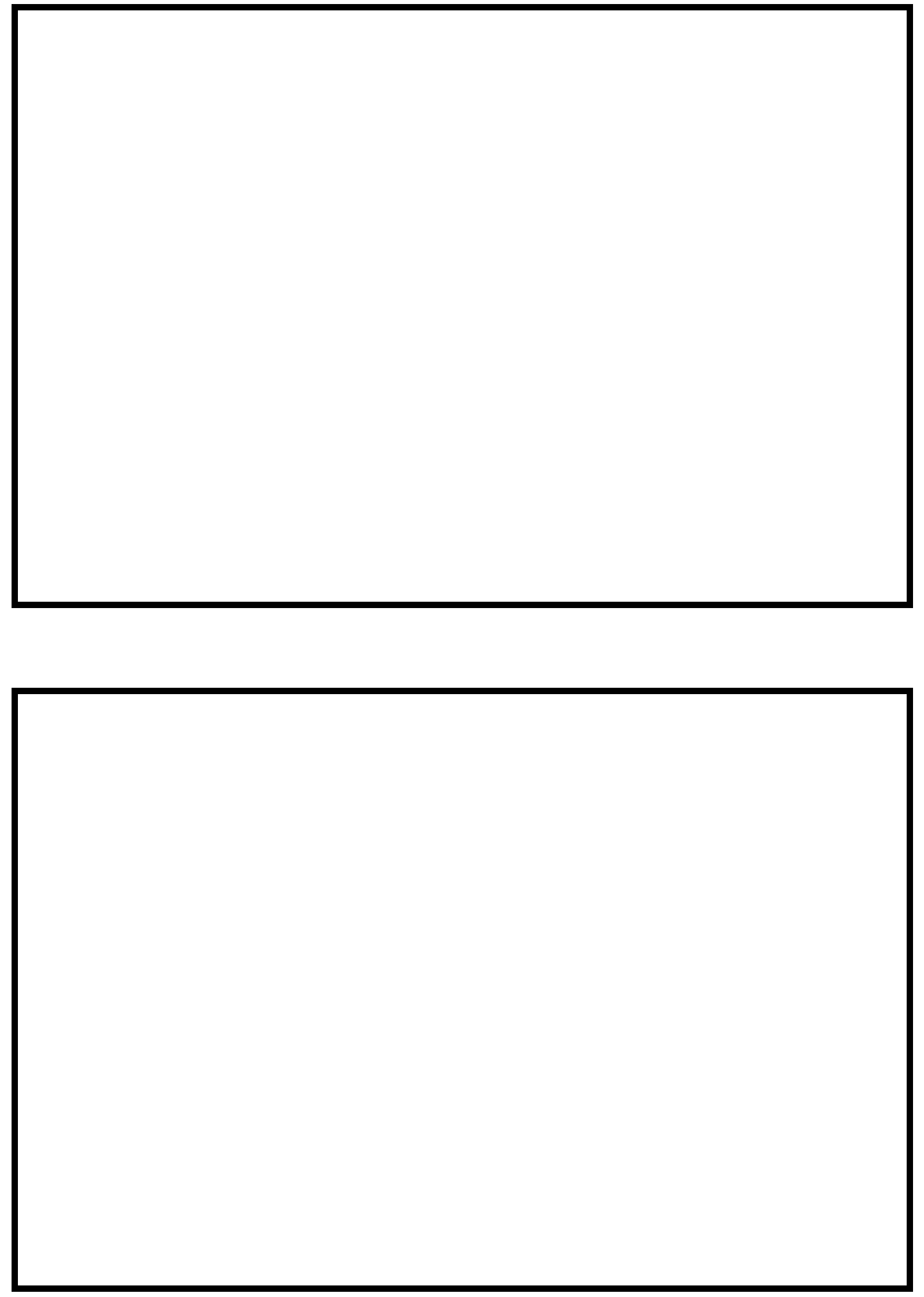


\section{LEVEL II SUMMARY}

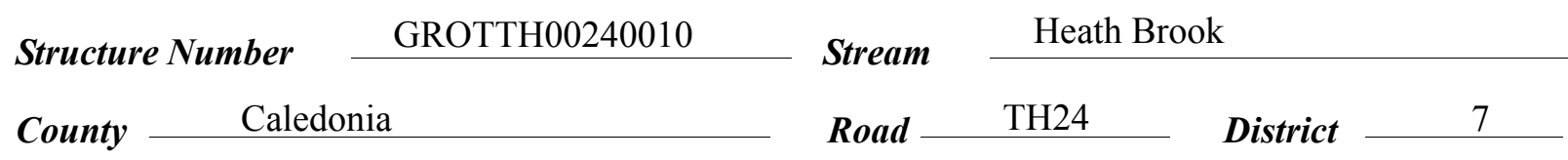

\section{Description of Bridge}

Bridge length $\frac{30}{4} \quad \boldsymbol{f t}$ Bridge width $\stackrel{25.4}{f} \quad$ Max span length $\frac{27}{f t}$ Alignment of bridge to road (on curve or straight)

Vertical, concrete

Abutment type

Stone fill on abutment? Yes
Curve, left; Straight, right

Sloping; near vertical

nosmintin.. af otan a fill

\section{Embankment type} $8 / 29 / 95$

Drto of incnortion Type-2, along the entire base length of the left and right abutment, upstream left and right wingwall, and downstream left and right wingwall.

Abutments and wingwalls are concrete. There is a $3 \mathrm{ft}$

scour hole from $15 \mathrm{ft}$ UB to $50 \mathrm{ft}$ DS.

Yes

30

Is bridge skewed to flood flow according to No ' survey? Angle

The reagch is straight

Debris accumulation on bridge at time of Level I or Level II site visit:

Date af insnortinn
$8 / 29 / 95$

$8 / 29 / 95$

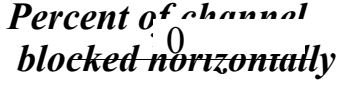

0
Percent of and nel
blocked verticatty 0

Level I

Moderate. There was no debris problems noted at the time of the

Level II

There was one log located in the USRWW area.

Potential for debris

None as of 8/29/95. 


\section{Description of the Geomorphic Setting}

General topography The channel is located within a moderate relief valley with a narrow flood plain.

Geomorphic conditions at bridge site: downstream (DS), upstream (US)

Date of inspection $\quad 8 / 29 / 95$

DS left: $\quad$ Steep channel bank to moderately sloping overbank and confluence

DS right: $\quad$ Steep channel bank to flood plain

US left: $\quad$ Steep channel bank to moderately sloping overbank

US right: $\quad$ Steep channel bank to flood plain

\section{Description of the Channel}

\begin{tabular}{|c|c|c|c|}
\hline \multirow[b]{2}{*}{ Average top width } & & \multirow[b]{2}{*}{ Average depth } & \multirow[b]{2}{*}{ Boulder/Sand } \\
\hline & $\stackrel{\boldsymbol{f t}}{\text { Boulder/ Cobbles }}$ & & \\
\hline Predominant bed m & & Bank material & Straight and stable \\
\hline
\end{tabular}

with non-alluvial channel boundaries and a narrow flood plain."

$8 / 29 / 95$

Vegetative col Tall and short grass with a few bushes; trees beyond $1 \mathrm{~B}$ on immediate bank

DS left: $\quad$ Pasture

DS right: $\quad$ Tall grass and bushes: trees beyond 1B on immediate bank

US left: $\quad$ Pasture

US right: $\quad$ Yes

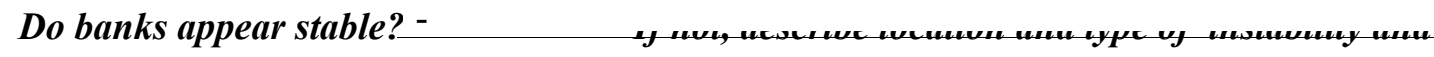

date oj observation.

None observed on

$8 / 29 / 95$.

Describe any obstructions in channel and date of observation. 


\section{Hydrology}

Drainage area $\quad 5.6 \quad \mathbf{m i}^{2}$

Percentage of drainage area in physiographic provinces: (approximate)

Physiographic province/section New England/New England Upland
Percent of drainage area 100
Is drainage area considered rural or urban?
Rural urbanization: None.
Describe any significant

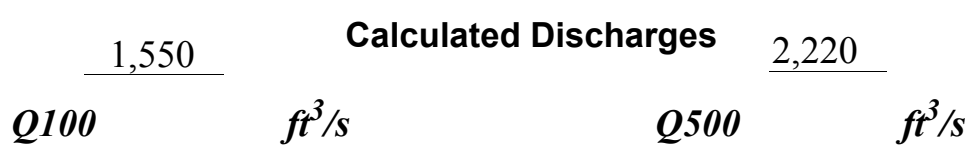

The 100- and 500-year discharges are taken directly

from flood frequency estimates available from the VTAOT database and are within a range of other empirical flood frequency curves. (Benson, 1962; Johnson and Tasker, 1974; FHWA, 1983; Potter, 1957a\&b; Talbot, 1887). Each curve was extended graphically to the 500-year event. 


\section{Description of the Water-Surface Profile Model (WSPRO) Analysis}

Datum for WSPRO analysis (USGS survey, sea level, VTAOT plans)

USGS survey

Datum tie between USGS survey and VTAOT plans

Subtract $0.7 \mathrm{ft}$ from USGS survey

to obtain NGVD of 1929 (also VTAOT). Datum tie points: USRAB and DSLAB.

Description of reference marks used to determine USGS datum. $\quad$ RM1 is a chiseled X on

top of the downstream end of the left abutment (elev. $1271.76 \mathrm{ft}$, arbitrary survey datum). RM2

is a brass survey disk on top of the downstream end of the right abutment (elev. $1270.35 \mathrm{ft}$,

arbitrary survey datum).

\section{Cross-Sections Used in WSPRO Analysis}

\begin{tabular}{|c|c|c|c|}
\hline${ }^{1}$ Cross-section & $\begin{array}{l}\text { Section } \\
\text { Reference } \\
\text { Distance } \\
\text { (SRD) in feet }\end{array}$ & $\begin{array}{c}{ }^{2} \text { Cross-section } \\
\text { development }\end{array}$ & Comments \\
\hline EXITF & -40 & 3 & $\begin{array}{l}\text { Exit section (EXITX sec- } \\
\text { tion with elevation adjust- } \\
\text { ments) }\end{array}$ \\
\hline EXITX & -7 & 1 & Exit section \\
\hline FULLV & 0 & 2 & $\begin{array}{l}\text { Downstream Full-valley } \\
\text { section (Templated from } \\
\text { EXITX) }\end{array}$ \\
\hline BRIDG & 0 & 1 & Bridge section \\
\hline RDWAY & 18 & 1 & Road Grade section \\
\hline APTEM & 65 & 2 & $\begin{array}{l}\text { Approach section as sur- } \\
\text { veyed (Used as a tem- } \\
\text { plate) }\end{array}$ \\
\hline APPRO & 76 & 1 & $\begin{array}{l}\text { Modelled Approach sec- } \\
\text { tion (Templated from } \\
\text { APTEM) }\end{array}$ \\
\hline
\end{tabular}

${ }^{1}$ For location of cross-sections see plan-view sketch included with Level I field form, Appendix E. For more detail on how cross-sections were developed see WSPRO input file. 


\section{Data and Assumptions Used in WSPRO Model}

Hydraulic analyses of the reach were done by use of the Federal Highway Administration's WSPRO step-backwater computer program (Shearman and others, 1986, and Shearman, 1990). The analyses reported herein reflect conditions existing at the site at the time of the study. Furthermore, in the development of the model it was necessary to assume no accumulation of debris or ice at the site. Results of the hydraulic model are presented in the Bridge Hydraulic Summary, appendix B, and figure 7.

Channel roughness factors (Manning's " $n$ ") used in the hydraulic model were estimated using field inspections at each cross section following the general guidelines described by Arcement and Schneider (1989). Final adjustments to the values were made during the modelling of the reach. Channel " $n$ " values for the reach ranged from 0.035 to 0.045 , and overbank " $\mathrm{n}$ " values ranged from 0.035 to 0.045 .

The surveyed exit section (EXITX) was copied and placed one bridge length downstream of the site with elevation adjustments. These adjustments were made using a slope of $0.0134 \mathrm{ft} / \mathrm{ft}$ which was taken from points surveyed downstream of the site. Starting water surface elevations for the 100-year, 500-year, and incipient overtopping discharge at the adjusted exit section (EXITF) were estimated from a rating curve developed from water surface profiles generated in the Flood Insurance Study (FIS) for the Town of Groton (Federal Emergency Management Agency, 1991).

The surveyed approach section (APTEM) was moved along the approach channel slope $(0.0308 \mathrm{ft} / \mathrm{ft})$ to establish the modelled approach section (APPRO), one bridge length upstream of the upstream face as recommended by Shearman and others (1986). This location also provides a consistent method for determining scour variables.

For the incipient-overtopping discharge, WSPRO assumes critical depth at the bridge section. A supercritical model was developed for this discharge. After analyzing both the supercritical and subcritical profiles for the incipient-overtopping discharge, it was determined that the water surface profile does pass through critical depth within the bridge opening. Thus, the assumption of critical depth at the bridge is a satisfactory solution. 


\section{Bridge Hydraulics Summary}

$\begin{array}{llrl}\text { Average bridge embankment elevation } & 1272.3 & f t \\ \text { Average low steel elevation } & 1270.5 & \boldsymbol{f t}\end{array}$

100-year discharge $\quad 1,550 \quad \mathrm{ft}^{3} / \mathrm{s}$

Water-surface elevation in bridge opening $1271.1 \mathrm{ft}$

Road overtopping? ___ Yes Discharge over road __ $37 \quad \mathrm{ft}^{3} / \mathrm{s}$

\begin{tabular}{llcc} 
Area of flow in bridge opening & $172 \quad \boldsymbol{f t}^{2}$ \\
\cline { 2 - 3 } Average velocity in bridge opening & 8.8 & $\boldsymbol{f t} / \mathrm{s}$
\end{tabular}

Maximum WSPRO tube velocity at bridge $\quad 10.8 \mathrm{ft} / \mathrm{s}$

Water-surface elevation at Approach section with bridge 1272.5

Water-surface elevation at Approach section without bridge $\quad \frac{1268.8}{2}$

Amount of backwater caused by bridge

$3.7 \quad i$

500-year discharge $\quad 2,220 \quad \mathrm{ft}^{3} / \mathrm{s}$

Water-surface elevation in bridge opening $1271.1 \mathrm{ft}$

Road overtopping? ___ Yes Discharge over road __ $774 \mathrm{ft}^{3} / \mathrm{s}$

$\begin{array}{llll}\text { Area of flow in bridge opening } & 172 & \boldsymbol{f t}^{2} & \\ \text { velocity in bridge opening } & & 8.5 & \mathbf{f t} / \mathbf{s}\end{array}$

Maximum WSPRO tube velocity at bridge 10.3 , s

Water-surface elevation at Approach section with bridge

Water-surface elevation at Approach section without bridge

Amount of backwater caused by bridge 1.6 , $t$

1273.1

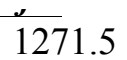

Incipient overtopping discharge $\quad 1,400 \quad \mathrm{ft}^{3} / \mathrm{s}$

Water-surface elevation in bridge opening $1267.6 \mathrm{t}$

Area of flow in bridge opening $\quad 109 \quad \mathrm{ft}^{2}$

Average velocity in bridge opening $\quad 12.8 \quad \mathrm{ft} / \mathrm{s}$

Maximum WSPRO tube velocity at bridge $16.0 \mathrm{ft} / \mathrm{s}$

Water-surface elevation at Approach section with bridge $\quad 1270.8$

Water-surface elevation at Approach section without bridge $\quad \frac{1268.3}{}$

Amount of backwater caused by bridge $\quad 2.5$ it 


\section{Scour Analysis Summary}

\section{Special Conditions or Assumptions Made in Scour Analysis}

Scour depths were computed using the general guidelines described in Hydraulic Engineering Circular 18 (Richardson and Davis, 1995). Scour depths were calculated assuming an infinite depth of erosive material and a homogeneous particle-size distribution. The results of the 100- and 500-year scour analysis are presented in tables 1 and 2 and a graph of the scour depths is presented in figure 8 .

At this site, the 100-year discharge resulted in unsubmerged orifice flow while the 500-year discharge resulted in submerged orifice flow. Contraction scour at bridges with orifice flow is best estimated by use of the Chang pressure-flow scour equation (oral communication, J. Sterling Jones, October 4, 1996). Thus, contraction scour for the 100- and 500-year discharges was computed by use of the Chang equation (Richardson and Davis, 1995, p. 145-146). Contraction scour for the incipient roadway-overtopping discharge was computed by use of the Laursen clear-water contraction scour equation (Richardson and Davis, 1995, p. 32, equation 20). The computed streambed armoring depths suggest that armoring will not limit the depth of contraction scour.

For comparison, contraction scour for the discharges resulting in orifice flow was also computed by use of the Laursen clear-water contraction scour equation and the Umbrell pressure-flow equation (Richardson and Davis, 1995, p. 144) and presented in appendix F. Furthermore, for the discharge resulting in unsubmerged orifice flow, contraction scour was computed by substituting estimates for the depth of flow at the downstream bridge face in the contraction scour equations. Results with respect to these substitutions are provided in appendix F.

Abutment scour for the left abutment was computed by use of the Froehlich equation (Richardson and Davis, 1995, p. 48, equation 28). Variables for the Froehlich equation include the Froude number of the flow approaching the embankments, the length of the embankment blocking flow, and the depth of flow approaching the embankment less any roadway overtopping.

Scour at the right abutment was computed by use of the HIRE equation (Richardson and Davis, 1995, p. 49, equation 29) because the HIRE equation is recommended when the length to depth ratio of the embankment blocking flow exceeds 25 . The variables used by the HIRE abutment-scour equation are defined the same as those defined for the Froehlich abutment-scour equation. 


\section{Scour Results}

$$
\text { 100-yr discharge 500-yr discharge }
$$

Contraction scour:

Main channel

Live-bed scour

Clear-water scour

Depth to armoring

Left overbank

Right overbank

Local scour:

Abutment scour

Left abutment

Right abutment

Pier scour

Pier 1

Pier 2

Pier 3
7.6

$5.2-$
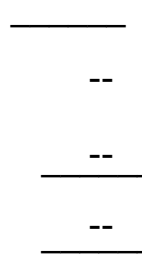

(Scour depths in feet)

overtopping discharge

\section{(Scour depths in feet)}

Incipient

\section{(1)}




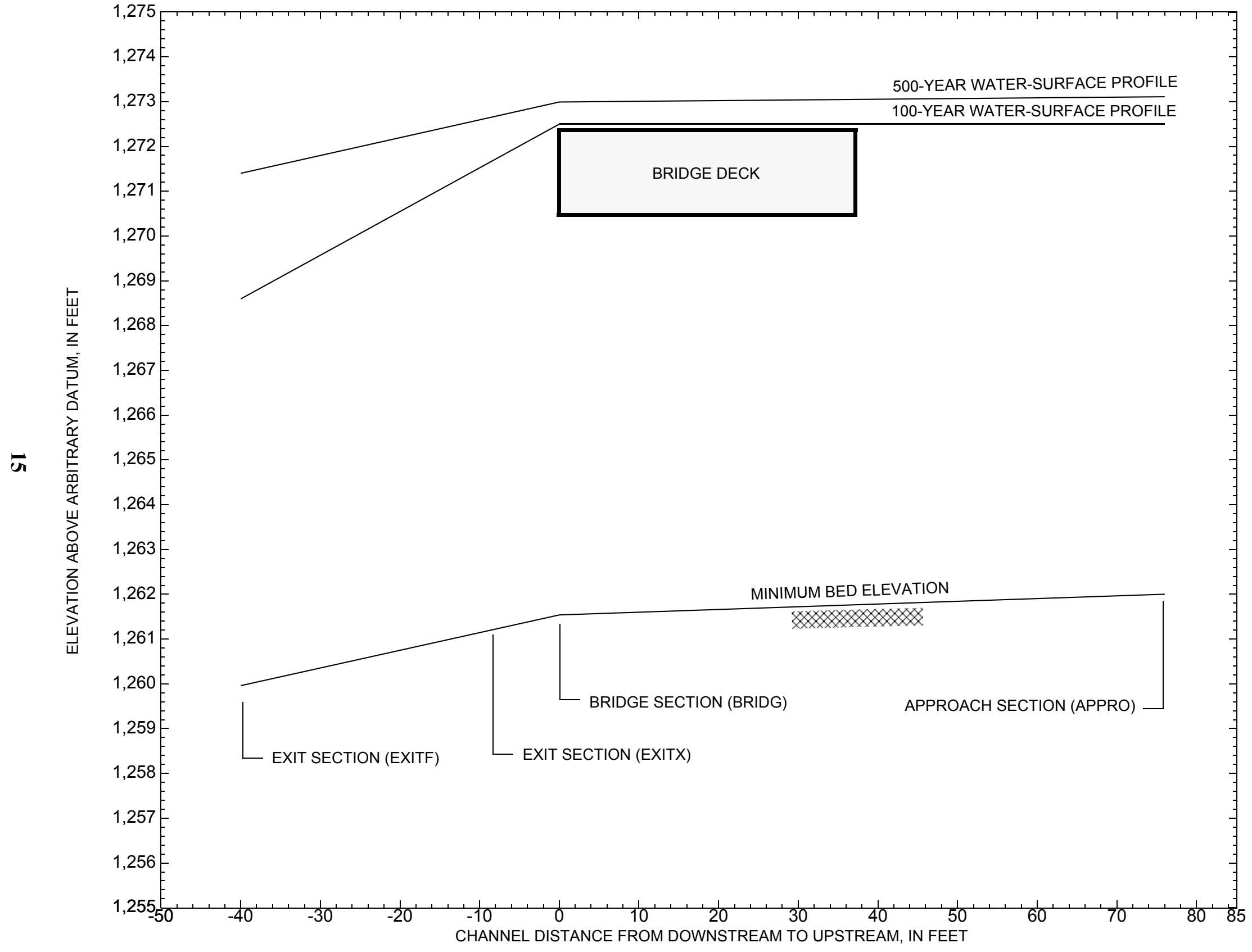

Figure 7. Water-surface profiles for the 100-year and 500-year discharges at structure GROTTH00240010 on Town Highway 24, crossing Heath Brook, Groton, Vermont. 


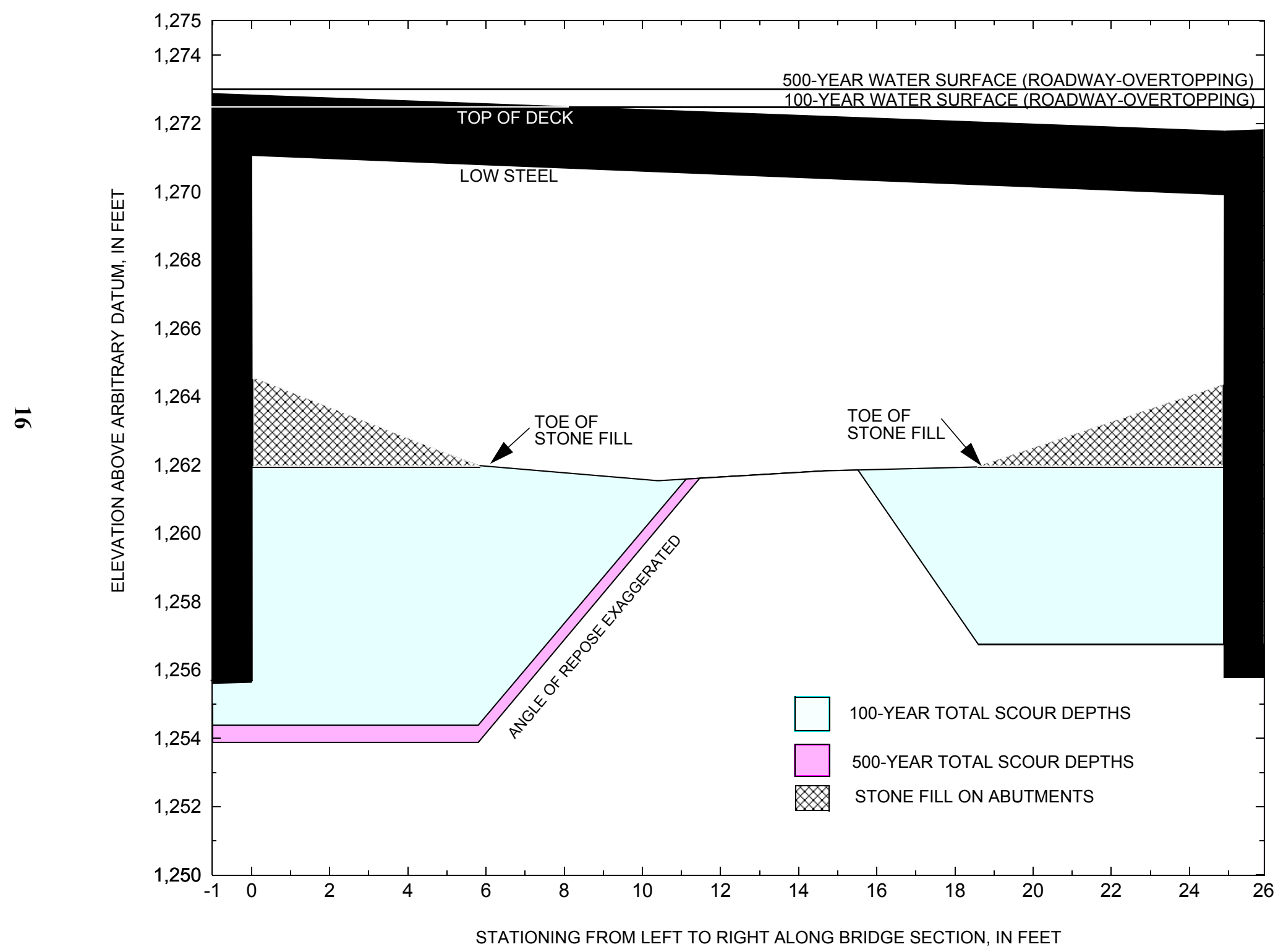

Figure 8. Scour elevations for the 100-year and 500-year discharges at structure GROTTH00240010 on Town Highway 24, crossing Heath Brook, Groton, Vermont. 
Table 1. Remaining footing/pile depth at abutments for the 100-year discharge at structure GROTTH00240010 on Town Highway 24, crossing Heath Brook, Groton, Vermont.

[VTAOT, Vermont Agency of Transportation; --,no data]

\begin{tabular}{|c|c|c|c|c|c|c|c|c|c|c|c|}
\hline Description & Station $^{1}$ & $\begin{array}{l}\text { VTAOT } \\
\text { minimum } \\
\text { low-chord } \\
\text { elevation } \\
\text { (feet) }\end{array}$ & $\begin{array}{l}\text { Surveyed } \\
\text { minimum } \\
\text { low-chord } \\
\text { elevation }{ }^{2} \\
\text { (feet) }\end{array}$ & $\begin{array}{c}\text { Bottom of } \\
\text { footing/pile } \\
\text { elevation } \\
\text { (feet) }\end{array}$ & $\begin{array}{l}\text { Channel } \\
\text { elevation at } \\
\text { abutment/ } \\
\text { pier }^{2} \\
\text { (feet) }\end{array}$ & $\begin{array}{l}\text { Contraction } \\
\text { scour depth } \\
\text { (feet) }\end{array}$ & $\begin{array}{l}\text { Abutment } \\
\text { scour } \\
\text { depth } \\
\text { (feet) }\end{array}$ & $\begin{array}{l}\text { Pier } \\
\text { scour } \\
\text { depth } \\
\text { (feet) }\end{array}$ & $\begin{array}{l}\text { Depth of } \\
\text { total scour } \\
\text { (feet) }\end{array}$ & $\begin{array}{c}\text { Elevation of } \\
\text { scour }^{2} \\
\text { (feet) }\end{array}$ & $\begin{array}{c}\text { Remaining } \\
\text { footing/pile } \\
\text { depth } \\
\text { (feet) }\end{array}$ \\
\hline \multicolumn{12}{|c|}{100 -yr. discharge is 1,550 cubic-feet per second } \\
\hline Left abutment & 0.0 & 1271.2 & 1271.1 & 1255.7 & 1264.5 & -- & -- & -- & -- & -- & -1.3 \\
\hline $\begin{array}{c}\text { Toe of } \\
\text { Stone Fill }\end{array}$ & 5.8 & -- & -- & -- & 1262.0 & 0.0 & 7.6 & -- & 7.6 & 1254.4 & -- \\
\hline $\begin{array}{c}\text { Toe of } \\
\text { Stone Fill }\end{array}$ & 18.6 & -- & -- & -- & 1261.9 & 0.0 & 5.2 & -- & 5.2 & 1256.7 & -- \\
\hline Right abutment & 24.9 & 1271.2 & 1270.0 & 1255.7 & 1264.3 & -- & -- & -- & -- & -- & 1.0 \\
\hline
\end{tabular}

1.Measured along the face of the most constricting side of the bridge.

2.Arbitrary datum for this study.

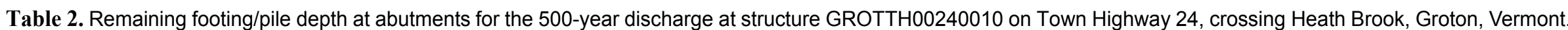
[VTAOT, Vermont Agency of Transportation; --, no data]

\begin{tabular}{|c|c|c|c|c|c|c|c|c|c|c|c|}
\hline Description & Station $^{1}$ & $\begin{array}{l}\text { VTAOT } \\
\text { minimum } \\
\text { low-chord } \\
\text { elevation } \\
\text { (feet) }\end{array}$ & $\begin{array}{l}\text { Surveyed } \\
\text { minimum } \\
\text { low-chord } \\
\text { elevation } \\
\quad \text { (feet) }\end{array}$ & $\begin{array}{c}\text { Bottom of } \\
\text { footing/pile } \\
\text { elevation }{ }^{2} \\
\text { (feet) }\end{array}$ & $\begin{array}{c}\text { Channel } \\
\text { elevation at } \\
\text { abutment/ } \\
\text { pier }^{2} \\
\text { (feet) }\end{array}$ & $\begin{array}{l}\text { Contraction } \\
\text { scour depth } \\
\text { (feet) }\end{array}$ & $\begin{array}{l}\text { Abutment } \\
\text { scour } \\
\text { depth } \\
\text { (feet) }\end{array}$ & $\begin{array}{l}\text { Pier } \\
\text { scour } \\
\text { depth } \\
\text { (feet) }\end{array}$ & $\begin{array}{l}\text { Depth of } \\
\text { total scour } \\
\text { (feet) }\end{array}$ & $\begin{array}{c}\text { Elevation of } \\
\text { scour }^{2} \\
\text { (feet) }\end{array}$ & $\begin{array}{c}\text { Remaining } \\
\text { footing/pile } \\
\text { depth } \\
\text { (feet) }\end{array}$ \\
\hline \multicolumn{12}{|c|}{500 -yr. discharge is 2,220 cubic-feet per second } \\
\hline Left abutment & 0.0 & 1271.2 & 1271.1 & 1255.7 & 1264.5 & -- & -- & -- & -- & -- & -1.8 \\
\hline $\begin{array}{c}\text { Toe of } \\
\text { Stone Fill }\end{array}$ & 5.8 & -- & -- & -- & 1262.0 & 0.0 & 8.1 & -- & 8.1 & 1253.9 & -- \\
\hline $\begin{array}{c}\text { Toe of } \\
\text { Stone Fill }\end{array}$ & 18.6 & -- & -- & -- & 1261.9 & 0.0 & 4.4 & -- & 4.4 & 1257.5 & -- \\
\hline Right abutment & 24.9 & 1271.2 & 1270.0 & 1255.7 & 1264.3 & -- & -- & -- & -- & -- & 1.8 \\
\hline
\end{tabular}

1.Measured along the face of the most constricting side of the bridge.

2.Arbitrary datum for this study. 


\section{SELECTED REFERENCES}

Arcement, G.J., Jr., and Schneider, V.R., 1989, Guide for selecting Manning's roughness coefficients for natural channels and flood plains: U.S. Geological Survey Water-Supply Paper 2339, 38 p.

Barnes, H.H., Jr., 1967, Roughness characteristics of natural channels: U.S. Geological Survey Water-Supply Paper 1849,213 p.

Benson, M. A., 1962, Factors Influencing the Occurrence of Floods in a Humid Region of Diverse Terrain: U.S. Geological Survey WaterSupply Paper 1580-B, 64 p.

Brown, S.A. and Clyde, E.S., 1989, Design of riprap revetment: Federal Highway Administration Hydraulic Engineering Circular No. 11, Publication FHWA-IP-89-016, 156 p.

Federal Emergency Management Agency, 1991, Flood Insurance Study, Town of Groton, Caledonia County, Vermont: Washington, D.C., September 1991.

Federal Highway Administration, 1983, Runoff estimates for small watersheds and development of sound design: Federal Highway Administration Report FHWA-RD-77-158.

Federal Highway Administration, 1993, Stream Stability and Scour at Highway Bridges: Participant Workbook: Federal Highway Administration Report FHWA-HI-91-011.

Froehlich, D.C., 1989, Local scour at bridge abutments in Ports, M.A., ed., Hydraulic Engineering--Proceedings of the 1989 National Conference on Hydraulic Engineering: New York, American Society of Civil Engineers, p. 13-18.

Hayes, D.C.,1993, Site selection and collection of bridge-scour data in Delaware, Maryland, and Virginia: U.S. Geological Survey WaterResources Investigation Report 93-4017, 23 p.

Interagency Advisory Committee on Water Data, 1982, Guidelines for determining flood flow frequency: U.S. Geological Survey, Bulletin 17B of the Hydrology Subcommittee, 190 p.

Johnson, C.G. and Tasker, G.D.,1974, Progress report on flood magnitude and frequency of Vermont streams: U.S. Geological Survey OpenFile Report 74-130, 37 p.

Lagasse, P.F., Schall, J.D., Johnson, F., Richardson, E.V., Chang, F., 1995, Stream Stability at Highway Structures: Federal Highway Administration Hydraulic Engineering Circular No. 20, Publication FHWA-IP-90-014, 144 p.

Laursen, E.M., 1960, Scour at bridge crossings: Journal of the Hydraulics Division, American Society of Civil Engineers, v. 86, no. HY2, p. 39-53.

Potter, W. D., 1957a, Peak rates of runoff in the Adirondack, White Mountains, and Maine woods area, Bureau of Public Roads

Potter, W. D., 1957b, Peak rates of runoff in the New England Hill and Lowland area, Bureau of Public Roads

Richardson, E.V. and Davis, S.R., 1995, Evaluating scour at bridges: Federal Highway Administration Hydraulic Engineering Circular No. 18, Publication FHWA-IP-90-017, 204 p.

Richardson, E.V., Simons, D.B., and Julien, P.Y., 1990, Highways in the river environment: Federal Highway Administration Publication FHWA-HI-90-016.

Ritter, D.F., 1984, Process Geomorphology: W.C. Brown Co., Debuque, Iowa, 603 p.

Shearman, J.O., 1990, User's manual for WSPRO--a computer model for water surface profile computations: Federal Highway Administration Publication FHWA-IP-89-027, 187 p.

Shearman, J.O., Kirby, W.H., Schneider, V.R., and Flippo, H.N., 1986, Bridge waterways analysis model; research report: Federal Highway Administration Publication FHWA-RD-86-108, 112 p.

Talbot, A.N., 1887, The determination of water-way for bridges and culverts.

U.S. Geological Survey, 1981, Knox Mountain, Vermont 7.5 Minute Series quadrangle map: U.S. Geological Survey Topographic Maps, Scale 1:24,000. 


\section{APPENDIX A: \\ WSPRO INPUT FILE}




\section{WSPRO INPUT FILE}

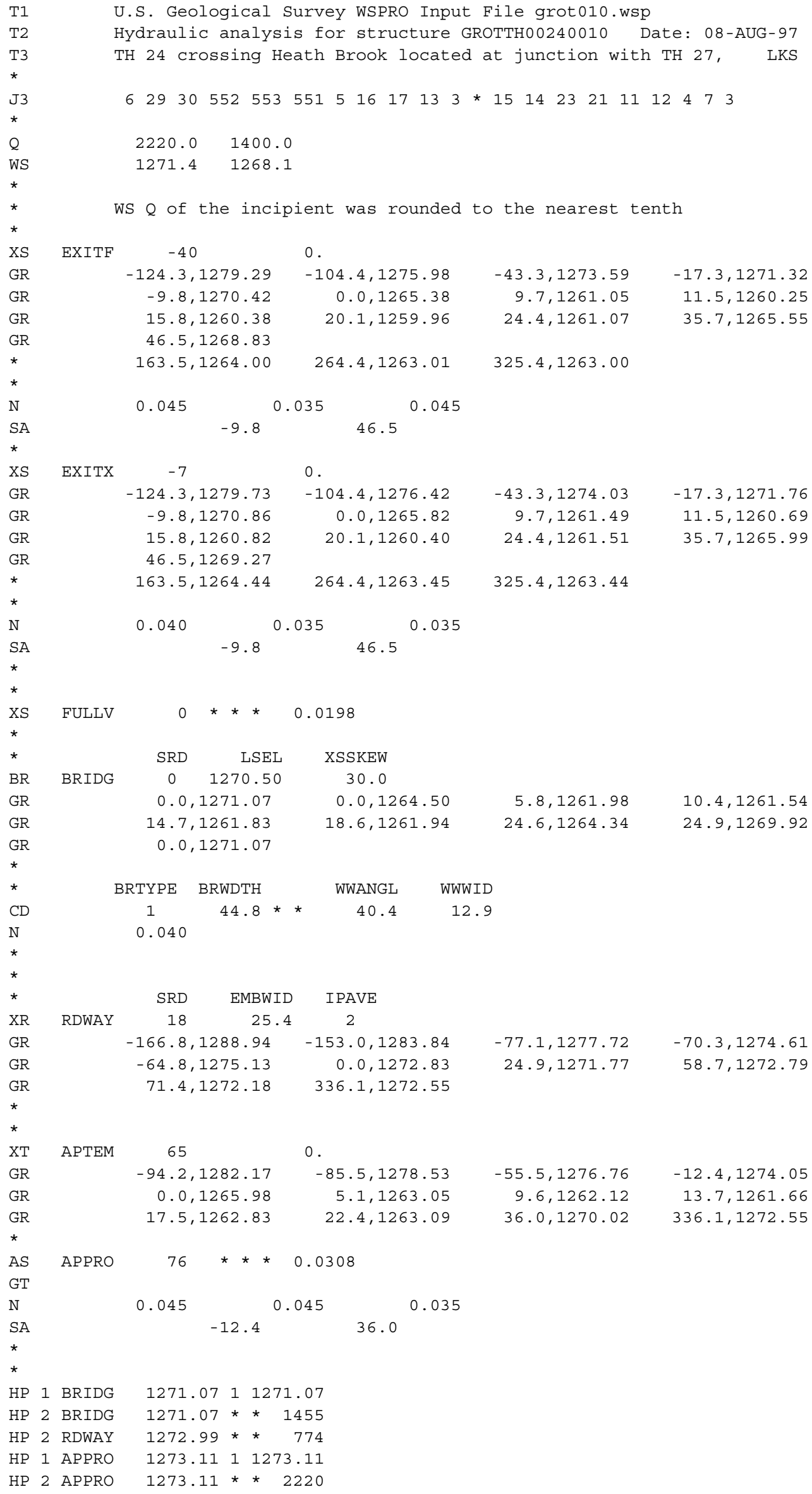


WSPRO INPUT FILE (continued)

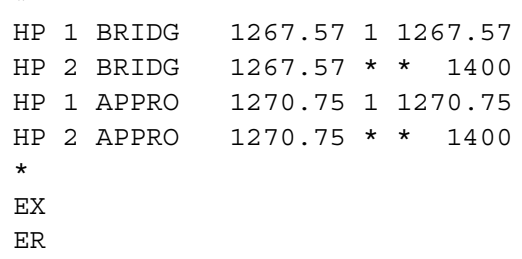

*

$\mathrm{EX}$

ER

U.S. Geological Survey WSPRO Input File grot010.wsp Hydraulic analysis for structure GROTTH00240010 Date: 08-AUG-97 TH 24 crossing Heath Brook located at junction with TH 27, LKS

* * 0.002

$\begin{array}{lllllllllllllllllllll}6 & 29 & 30 & 552 & 553 & 551 & 5 & 16 & 17 & 13 & 3 & * & 15 & 14 & 23 & 21 & 11 & 12 & 4 & 7 & 3\end{array}$

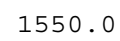




\section{APPENDIX B: \\ WSPRO OUTPUT FILE}




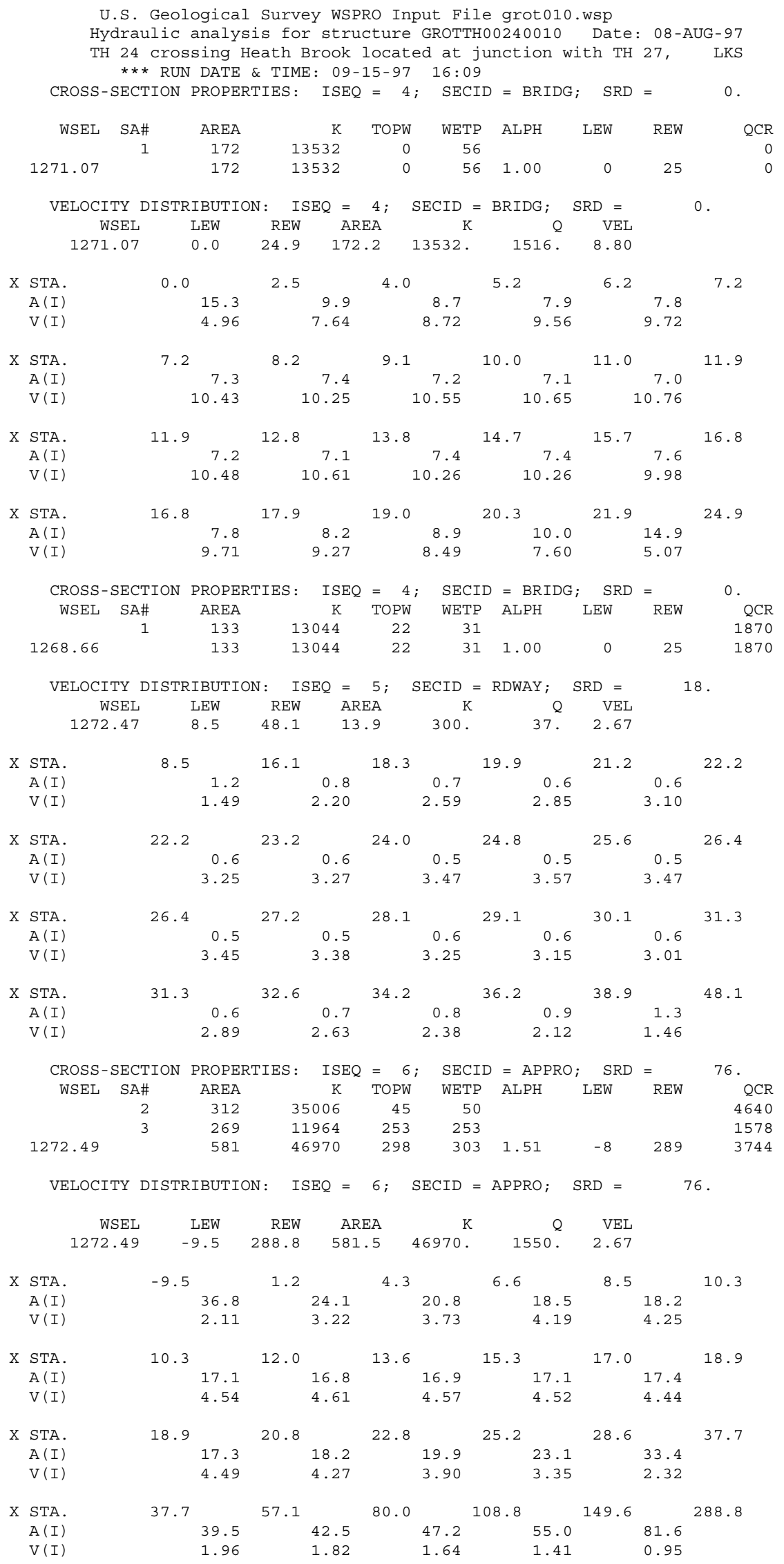


WSPRO OUTPUT FILE (continued)

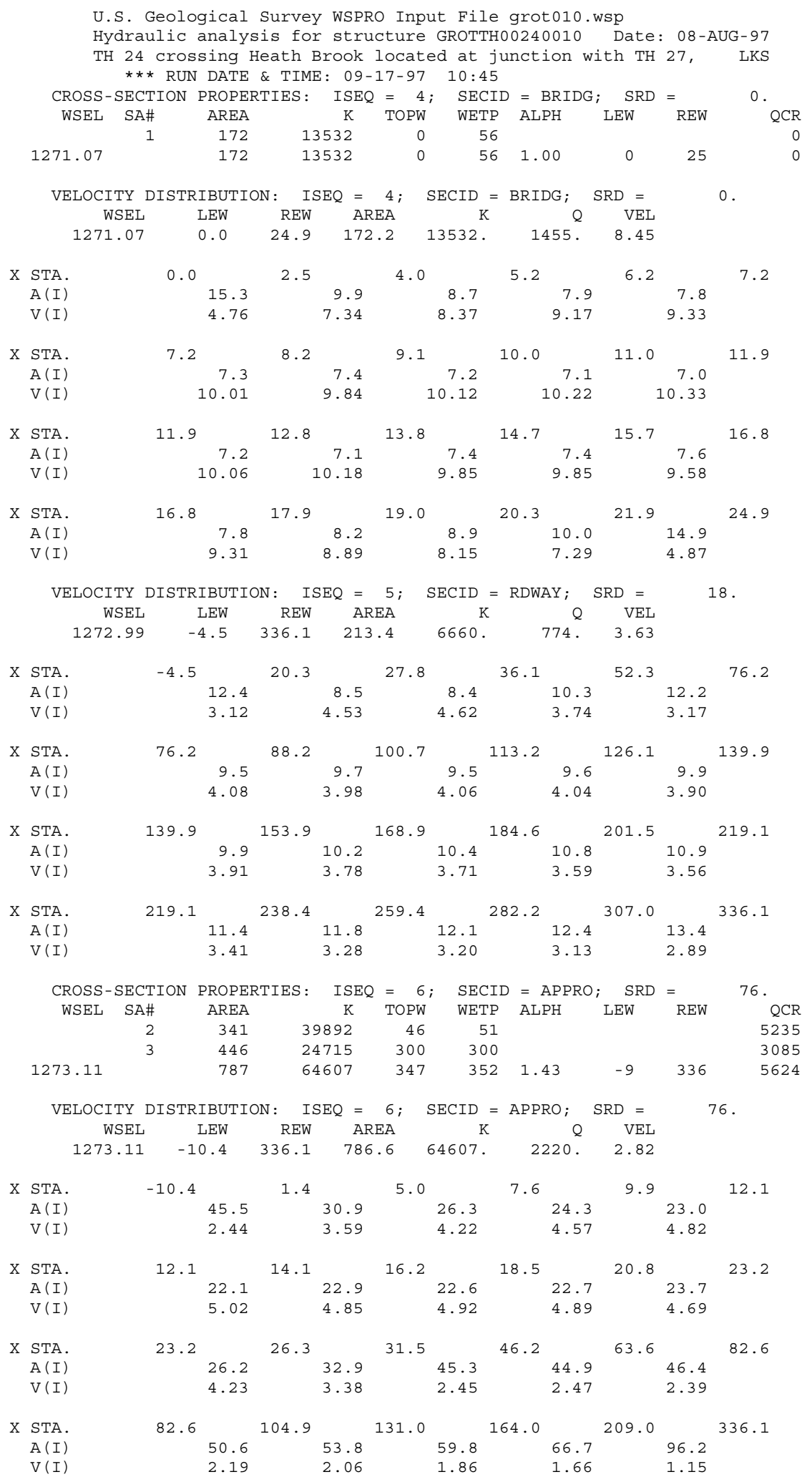


WSPRO OUTPUT FILE (continued)

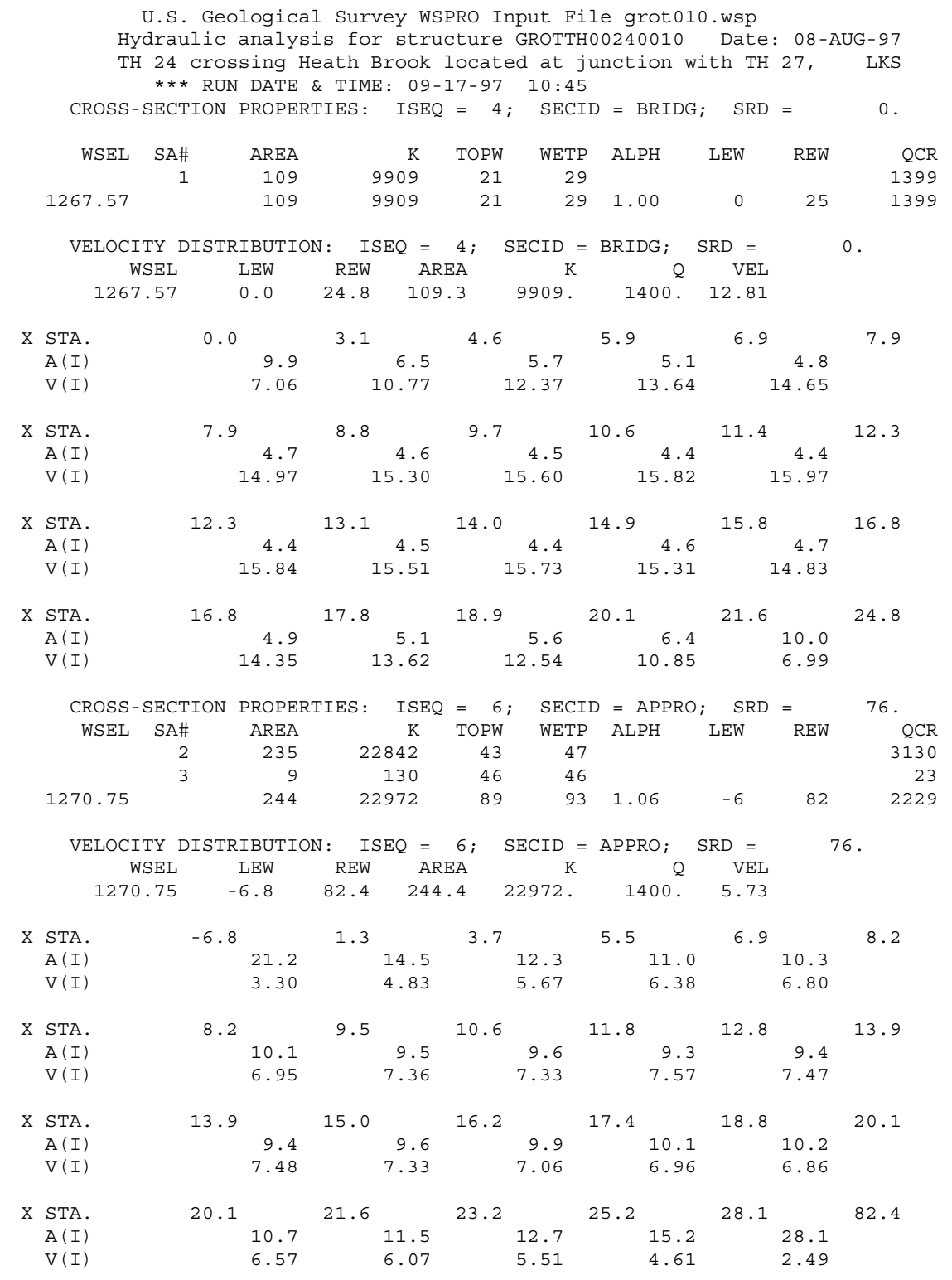


WSPRO OUTPUT FILE (continued)

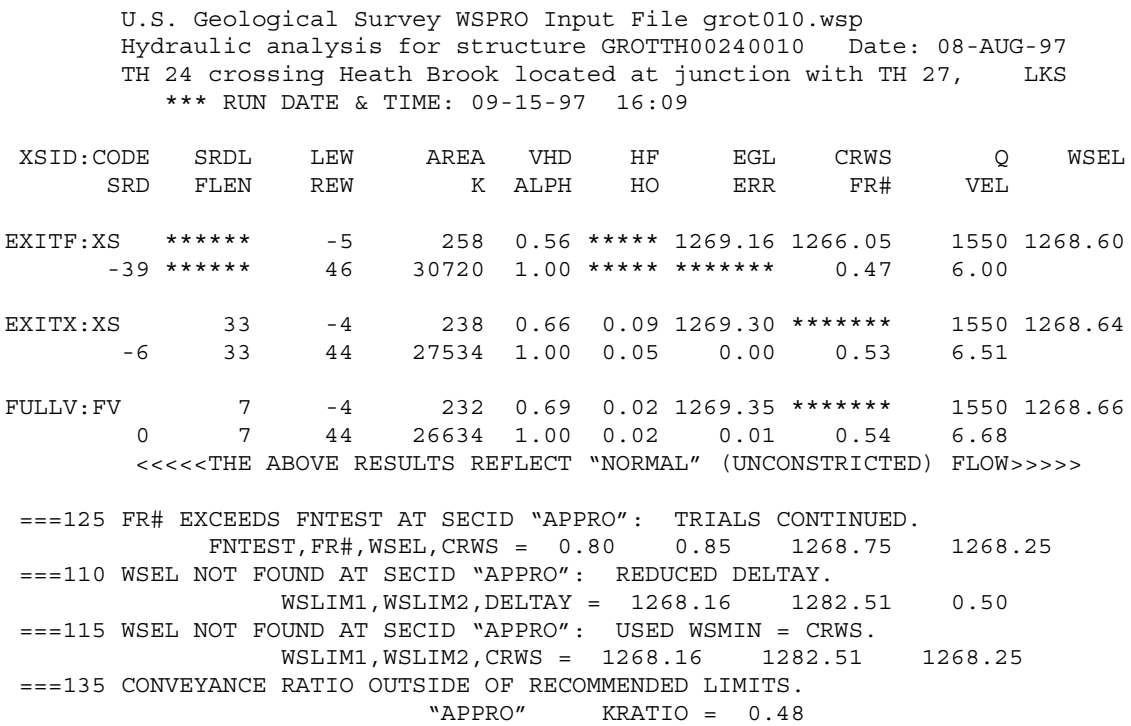


WSPRO OUTPUT FILE (continued)

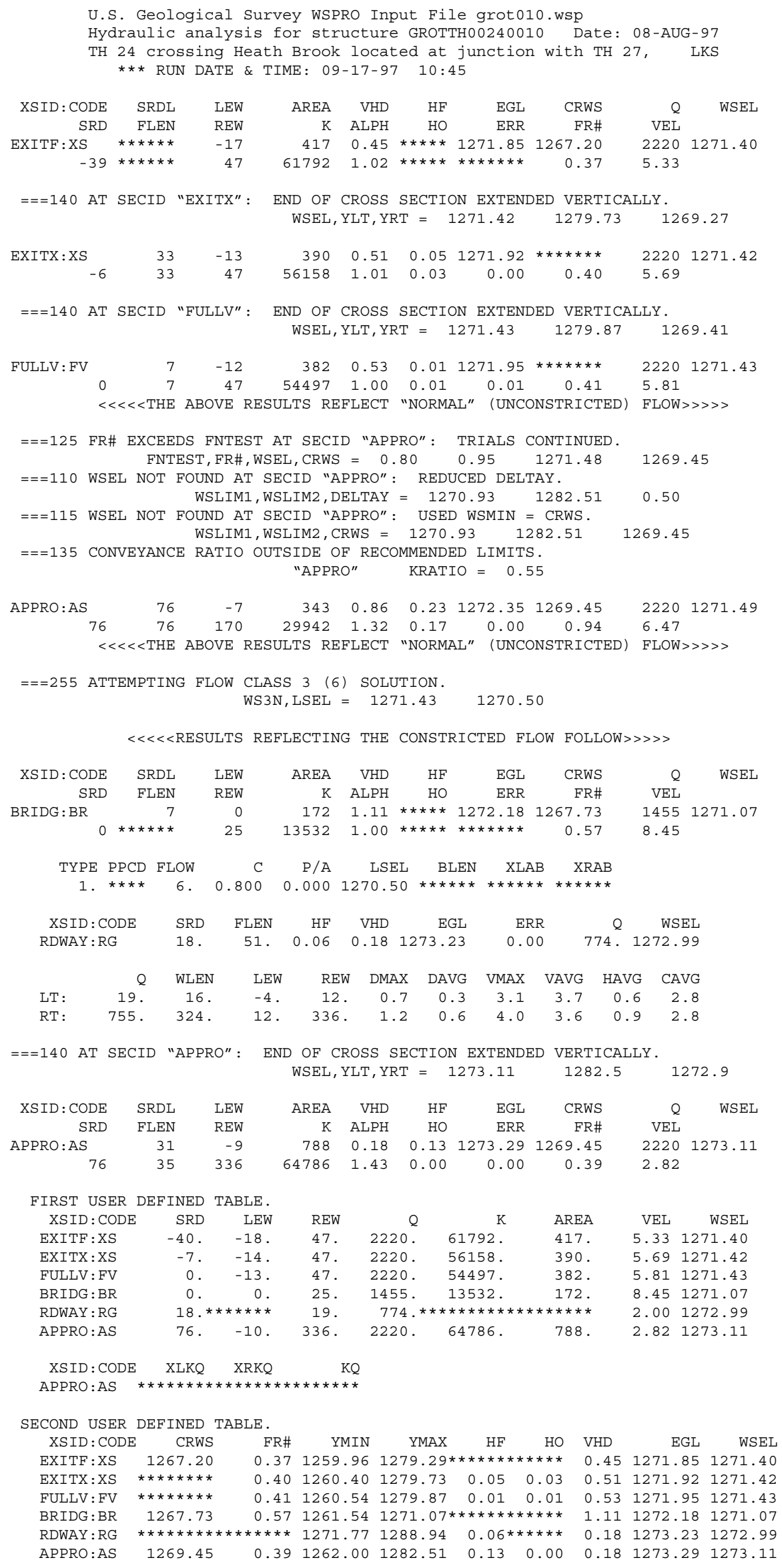


WSPRO OUTPUT FILE (continued)

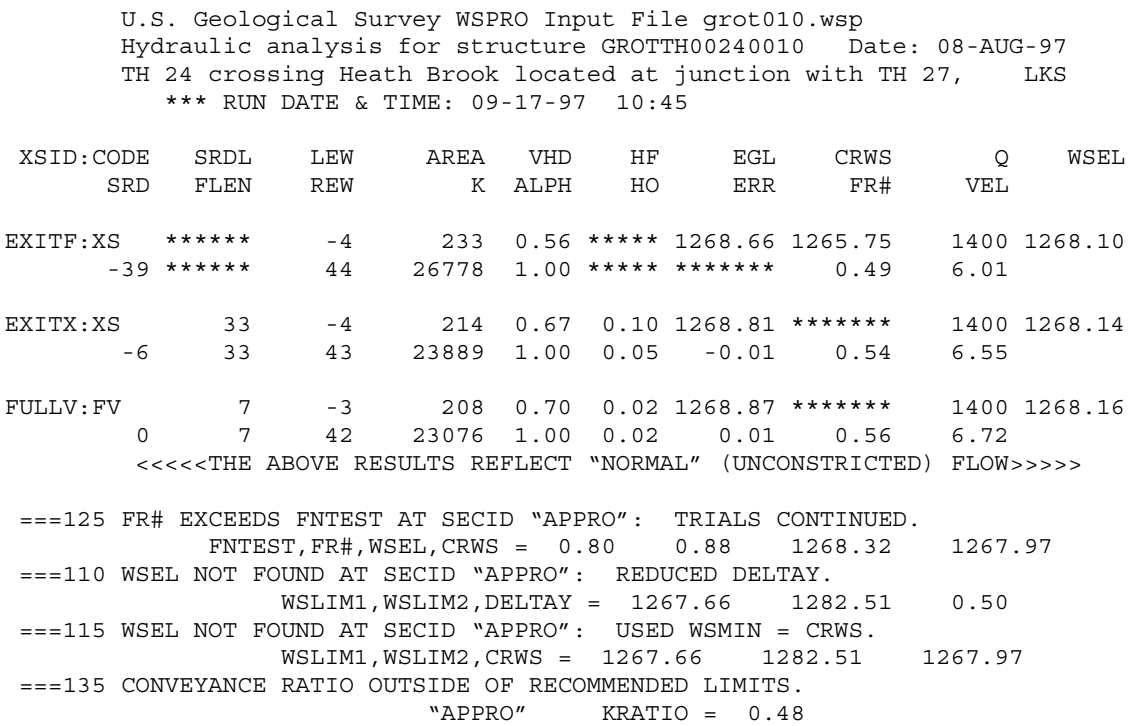

FIRST USER DEFINED TABLE.

\begin{tabular}{|c|c|c|c|c|c|c|c|c|}
\hline XSID : CODE & SRD & LEW & REW & $Q$ & K & AREA & VEL & WSEL \\
\hline EXITF:XS & -40 & -5 & 44. & 1400. & 26778 . & 233. & 6.01 & 1268.10 \\
\hline EXITX:XS & -7 . & -5 & 43. & 1400. & 23889 . & 214 & 6.55 & 1268.14 \\
\hline FULLV : FV & 0 . & -4 . & 42 . & 1400. & 23076 . & 208 . & 6.72 & 1268.16 \\
\hline BRIDG : BR & 0 . & 0 . & 25 . & 1400. & 9914. & 109. & 12.81 & 1267.57 \\
\hline RDWAY : RG & \multicolumn{3}{|c|}{$18 . * * \star * * * \star * * * \star * * *$} & \multicolumn{3}{|c|}{ 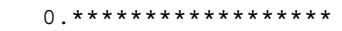 } & $2.00 \times$ & 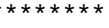 \\
\hline APPRO: AS & 76. & -7 & 83. & 1400. & 22990 . & 245. & 5.72 & 1270.7 \\
\hline XSID : CODE & XLKQ & XRKQ & & & & & & \\
\hline APPRO : AS & 1. & 26 . & $2257 \xi$ & & & & & \\
\hline
\end{tabular}

SECOND USER DEFINED TABLE.

$\begin{array}{lcrrrrrrrr}\text { XSID : CODE } & \text { CRWS } & \text { FR\# } & \text { YMIN } & \text { YMAX } & \text { HF } & \text { HO } & \text { VHD } & \text { EGL } & \text { WSEL } \\ \text { EXITF :XS } & 1265.75 & 0.49 & 1259.96 & 1279.29 * * * * * * * * * * * & 0.56 & 1268.66 & 1268.10 \\ \text { EXITX:XS } & * * * * * * * * & 0.54 & 1260.40 & 1279.73 & 0.10 & 0.05 & 0.67 & 1268.81 & 1268.14 \\ \text { FULLV:FV } & * * * * * * * * & 0.56 & 1260.54 & 1279.87 & 0.02 & 0.02 & 0.70 & 1268.87 & 1268.16 \\ \text { BRIDG:BR } & 1267.57 & 1.00 & 1261.54 & 1271.07 * * * * * * * * * * * & 2.55 & 1270.12 & 1267.57 \\ \text { RDWAY:RG } & * * * * * * * * * * * * * * * * & 1271.77 & 1288.94 * * * * * * * * * * * * * * * * * * * * * * * * * * * * * * * \\ \text { APPRO:AS } & 1267.97 & 0.63 & 1262.00 & 1282.51 & 0.28 & 0.89 & 0.54 & 1271.29 & 1270.75\end{array}$




\section{APPENDIX C:}

\section{BED-MATERIAL PARTICLE-SIZE DISTRIBUTION}




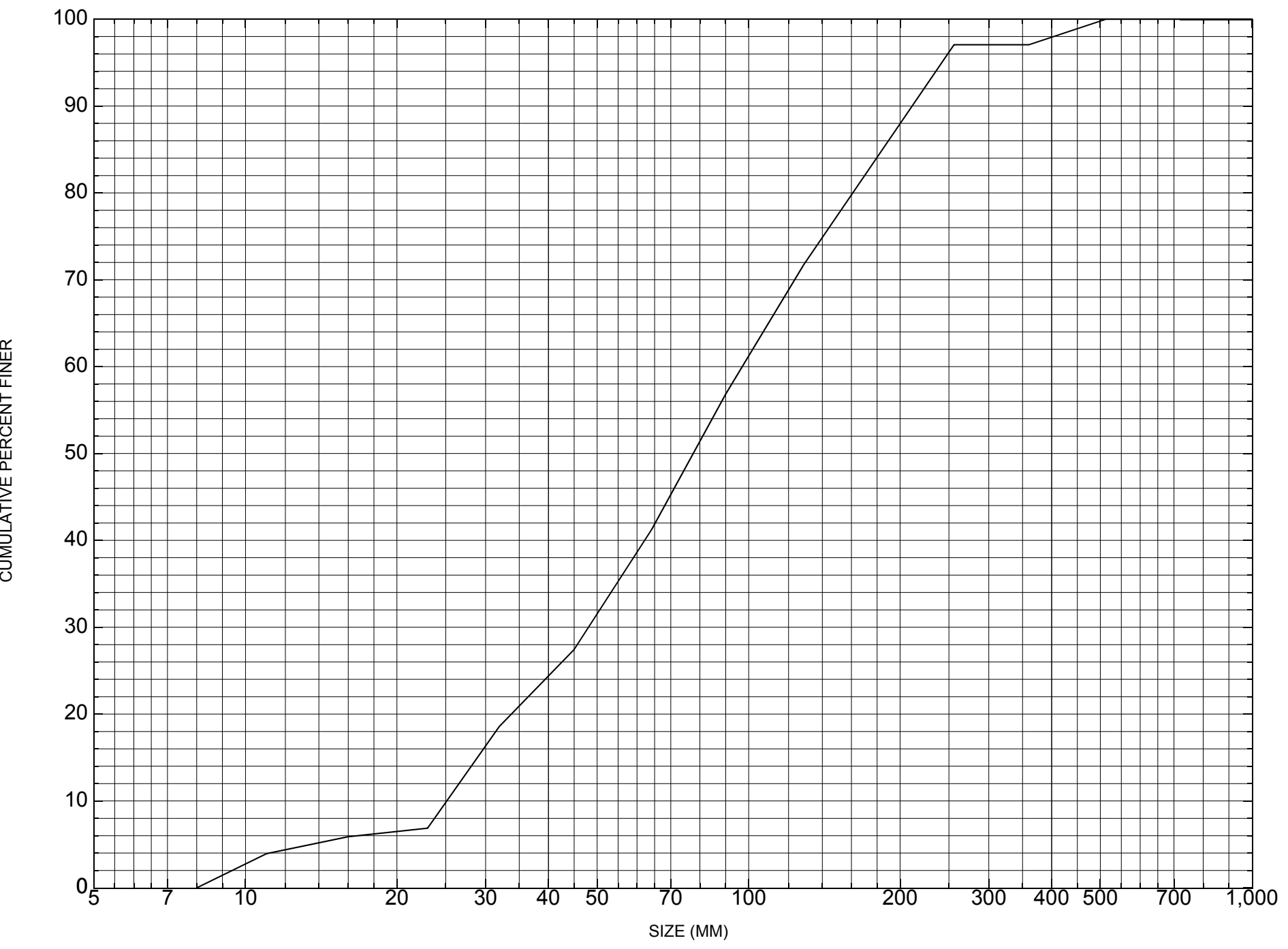

Appendix C. Bed material particle-size distribution for a pebble count in the channel approach of structure GROTTH00240010, in Groton, Vermont. 


\section{APPENDIX D: \\ HISTORICAL DATA FORM}




\section{Structure Number GROTTH00240010}

\section{General Location Descriptive}

Data collected by (First Initial, Full last name) $\mathbf{E}$. BOEHMLER

Date $(M M / D D / Y Y) \_\mathbf{0 3} / \underline{17} / \underline{95}$

Highway District Number (I - 2; nn) $\mathbf{0 7}$

Town (FIPS place code; I - 4; nnnnn) $\mathbf{3 0 5 5 0}$

Waterway (I - 6) HEATH BROOK

Route Number TH024

Topographic Map Knox Mountain

Latitude (I - 16; nnnn.n) $\mathbf{4 4 1 3 3}$
County (FIPS county code; I - 3; nnn)

Mile marker (I - 11; nnn.nnn) $\mathbf{0 0 0 0 0 0}$

Road Name (I - 7): SEYON POND ROAD

Vicinity (I - 9)@JCT W CL3 TH27

Hydrologic Unit Code: $\mathbf{0 1 0 8 0 1 0 2}$

Longitude (i - 17; nnnnn.n) $\mathbf{7 2 1 6 3}$

\section{Select Federal Inventory Codes}

FHWA Structure Number (I - 8) $\mathbf{1 0 0 3 0 4 0 0 1 0 0 3 0 4}$

Maintenance responsibility $(I-21 ; n n) \quad \mathbf{0 3}$

Year built (I - 27; YYYY) 1988

Average daily traffic, ADT (I - 29; nnnnnn) 000080

Year of ADT (I - 30; YY) $\mathbf{9 3}$

Opening skew to Roadway $(I-34 ; n n) \quad \mathbf{2 8}$

Operational status $(I-41 ; X)$ A

Structure type (I - 43; nnn) 101

Approach span structure type $(I-44 ; n n n) \quad \mathbf{0 0 0}$

Number of spans (I - 45; nnn) $\mathbf{0 0 1}$

Number of approach spans (I - 46; nnnn) $\mathbf{0 0 0 0}$

Comments:

The structural inspection report of 6/29/93 indicates the structure is a concrete slab type bridge. The deck is slightly curved. The abutment walls and wingwalls are concrete. Overall, the abutment concrete has fine cracks and small leaks reported at the top corners of each wall. There is stone and boulder fill protection noted as placed in front of the abutment walls and wingwalls. The stone fill is further noted as extending along the banks upstream and downstream. The bridge is fairly new. The channel bed is reported as composed of mainly boulders. The footings are not in view at the surface with no undermining or settling apparent.
Maximum span length (I - 48; nnnn) $\underline{\mathbf{0 0 2 7}}$

Structure length (I - 49; nnnnnn) $\underline{\mathbf{0 0 0 0 3 0}}$

Deck Width (I- 52; nn.n) 254

Channel \& Protection $(I-61 ; n) \underline{8}$

Waterway adequacy $(I-71 ; n) \underline{7}$

Underwater Inspection Frequency $(I-92 B ; X Y Y) \_$N

Year Reconstructed (I - 106) $\mathbf{0 0 0 0}$

Clear span (nnn.n ft) $\quad \mathbf{0 2 2 . 4}$

Vertical clearance from streambed (nnn.n ft) $\underline{\mathbf{0 0 7 . 0}}$

Waterway of full opening $\left(n n n . n \mathrm{ft}^{2}\right) \underline{\mathbf{1 8 0 . 0}}$ 


\section{Bridge Hydrologic Data}

Is there hydrologic data available? $\underline{\mathbf{Y}}$ if No, type ctrl- $h \quad$ VTAOT Drainage area $\left(m i^{2}\right): \underline{\mathbf{5 . 6}}$

Terrain character: Hilly to mountainous

Stream character \& type: Straight

Streambed material: Gravel and small boulders

Discharge Data (cfs): $\quad Q_{2.33} \frac{375}{1300}$

$\mathrm{Q}_{50} \mathbf{1 3 0 0}$

$Q_{10} \frac{\mathbf{7 5 0}}{1550}$

$\mathrm{Q}_{25}$

$Q_{500}$

Record flood date $(M M / D D / Y Y)$ :

Water surface elevation $(f t):-$

Estimated Discharge (cfs): I

Velocity at $\mathrm{Q} \mathbf{2 5}$ $(\mathrm{ft} / \mathrm{s}): \mathbf{1 0 . 9}$

Ice conditions (Heavy, Moderate, Light): Moderate Debris (Heavy, Moderate, Light): Light

The stage increases to maximum highwater elevation (Rapidly, Not rapidly): Rapidly

The stream response is (Flashy, Not flashy): Flashy

Describe any significant site conditions upstream or downstream that may influence the stream's

stage: Downstream Heath brook joins the South Branch Wells River, which may backwater up through the bridge.

Watershed storage area (in percent): 1

The watershed storage area is: 2 (1-mainly at the headwaters; 2- uniformly distributed; 3-immediatly upstream oi the site)

Water Surface Elevation Estimates for Existing Structure:

\begin{tabular}{|l|l|c|c|l|l|}
\hline Peak discharge frequency & $Q_{2.33}$ & $Q_{10}$ & $Q_{25}$ & $Q_{50}$ & $Q_{100}$ \\
Water surface elevation (ft) $)$ & $\mathbf{1 2 6 4 . 5}$ & $\mathbf{1 2 6 6 . 4}$ & $\mathbf{1 2 6 7 . 6}$ & $\mathbf{1 2 6 8 . 5}$ & $\mathbf{1 2 6 9 . 2}$ \\
Velocity $(\mathrm{ft} / \mathrm{sec})$ & $\mathbf{9 . 4}$ & $\mathbf{1 2 . 7}$ & $\mathbf{1 4 . 7}$ & $\mathbf{1 6 . 0}$ & $\mathbf{1 6 . 6}$ \\
\hline
\end{tabular}

Long term stream bed changes: Scour expected is between 2 and 4 feet

Is the roadway overtopped below the $\mathbf{Q}_{100}$ ? (Yes, No, Unknown): $\mathbf{Y} \quad$ Frequency: $\mathbf{Q 3 5}$ Relief Elevation $(f t): \underline{\mathbf{1 2 6 8 . 0}}$ Discharge over roadway at $Q_{100}\left(f t^{3} / \mathrm{sec}\right)$ :

Are there other structures nearby? (Yes, No, Unknown): $\mathbf{U}$ Upstream distance (miles): Town: If No or Unknown, type ctrl-n os Highway No. : Structure No. : Year Built:

Clear span (ft): Clear Height $(f t):$ Full Waterway $\left(f t^{2}\right)$ : 
Downstream distance (miles): Town: Year Built:

Highway No. : Structure No. : Structure Type:

Clear span (ft): Clear Height $(f t)$ :

Full Waterway $\left(f^{2}\right)$ :

Comments:

Hydraulics section report of hydrology indicates the channel needs to be protected by type IV stone. There are no structures downstream of this bridge over Heath Brook as it drains into the South Branch Wells River immediately downstream. It is unknown if there are additional structures upstream of this bridge.

\section{USGS Watershed Data}

Watershed Hydrographic Data

Drainage area $(D A) \underline{\mathbf{5 . 6 3}}$

Watershed storage (ST)

Bridge site elevation

Main channel length 1270 3.90 $10 \%$ channel length elevation $\mathrm{mi}^{2}$ 0 $\%$ $\%$ ft $\mathrm{mi}$

Main channel slope

(S) 1340 $\mathrm{ft} \quad 85 \%$ channel length elevation $\mathrm{mi}^{2}$ Lake/pond/swamp area $\underline{\mathbf{0}}$ $\mathrm{ft} / \mathrm{mi}$

Watershed Precipitation Data

Average site precipitation in Average headwater precipitation in

Maximum 2yr-24hr precipitation event $(124,2)$ in

Average seasonal snowfall (Sn) $\mathrm{ft}$ 


\section{Bridge Plan Data}

Are plans available? $\underline{Y}$ If no, type ctrl-n pl Date issued for construction (MM/YYYY): $\underline{05}$ / 1987

Project Number TH 3516

Minimum channel bed elevation: 1259.5

Low superstructure elevation: USLAB $\underline{\mathbf{1 2 7 0 . 0 3}}$ DSLAB $\underline{\mathbf{1 2 6 8 . 9 3}}$ USRAB $\underline{\mathbf{1 2 6 8 . 8 8}}$ DSRAB $\underline{\mathbf{1 2 6 7 . 5 3}}$

Benchmark location description:

No specific benchmarks were shown on the plans. The plans provided some points with elevations: 1) The point on the top of the upstream right wingwall concrete at the streamward edge where the concrete slope changes from horizontal to downward, elevation 1271.17, and 2) The point at the same location as (1) but on the downstream left wingwall, elevation 1271.76.

Reference Point (MSL, Arbitrary, Other): MSL Datum (NAD27, NAD83, Other): NGVD1929

Foundation Type: 1 (1-Spreadfooting; 2-Pile; 3- Gravity; 4-Unknown)

If 1: Footing Thickness $\mathbf{2 . 5}$ Footing bottom elevation: $\underline{\mathbf{1 2 5 5 . 0}}$

If 2: Pile Type:___ (1-Wood; 2-Steel or metal; 3-Concrete) Approximate pile driven length:

If 3: Footing bottom elevation:

Is boring information available? $\mathbf{N}$ If no, type ctrl-n bi Number of borings taken: -

Foundation Material Type: $\mathbf{3}$ (1-regolith, 2-bedrock, 3-unknown)

Briefly describe material at foundation bottom elevation or around piles:

$-$

Comments:

This bridge crosses Heath Brook just upstream of the Heath Brook confluence with the South Branch Wells River. 


\section{Cross-sectional Data}

Is cross-sectional data available? $\underline{\mathbf{Y}}$ If no, type ctrl-n xs

Source (FEMA, VTAOT, Other)? VTAOT

Comments: There are several channel cross sections printed and kept with the plans and may be retrieved if needed. However, there are no reproducible bridge cross sections due to differences in VTAOT and USGS survey methods.

\begin{tabular}{|l|l|l|l|l|l|l|l|l|l|l|l|}
\hline Station & - & - & - & - & - & - & - & - & - & - & - \\
\hline Feature & - & - & - & - & - & - & - & - & - & - & - \\
\hline $\begin{array}{l}\text { Low chord } \\
\text { elevation }\end{array}$ & - & - & - & - & - & - & - & - & - & - & - \\
\hline $\begin{array}{l}\text { Bed } \\
\text { elevation }\end{array}$ & - & - & - & - & - & - & - & - & - & - & - \\
\hline $\begin{array}{l}\text { Low chord- } \\
\text { bed }\end{array}$ & - & - & - & - & - & - & - & - & - & - & - \\
\hline Station & - & - & - & - & - & - & - & - & - & - & - \\
\hline Feature & - & - & - & - & - & - & - & - & - & - & - \\
\hline $\begin{array}{l}\text { Low chord } \\
\text { elevation }\end{array}$ & - & - & - & - & - & - & - & - & - & - & - \\
\hline $\begin{array}{l}\text { Bed } \\
\text { elevation }\end{array}$ & - & - & - & - & - & - & - & - & - & - & - \\
\hline $\begin{array}{l}\text { Low chord- } \\
\text { bed }\end{array}$ & - & - & - & - & - & - & - & - & - & - & - \\
\hline
\end{tabular}

Source (FEMA, VTAOT, Other)?

Comments: -

\begin{tabular}{|l|l|l|l|l|l|l|l|l|l|l|l|}
\hline Station & - & - & - & - & - & - & - & - & - & - & - \\
\hline Feature & - & - & - & - & - & - & - & - & - & - & - \\
\hline $\begin{array}{l}\text { Low chord } \\
\text { elevation }\end{array}$ & - & - & - & - & - & - & - & - & - & - & - \\
\hline $\begin{array}{l}\text { Bed } \\
\text { elevation }\end{array}$ & - & - & - & - & - & - & - & - & - & - & - \\
\hline $\begin{array}{l}\text { Low chord- } \\
\text { bed }\end{array}$ & - & - & - & - & - & - & - & - & - & - & - \\
\hline Station & - & - & - & - & - & - & - & - & - & - & - \\
\hline Feature & - & - & - & - & - & - & - & - & - & - & - \\
\hline $\begin{array}{l}\text { Low chord } \\
\text { elevation }\end{array}$ & - & - & - & - & - & - & - & - & - & - & - \\
\hline $\begin{array}{l}\text { Bed } \\
\text { elevation }\end{array}$ & - & - & - & - & - & - & - & - & - & - & - \\
\hline $\begin{array}{l}\text { Low chord- } \\
\text { bed }\end{array}$ & - & - & - & - & - & - & - & - & - & - & - \\
\hline
\end{tabular}




\section{APPENDIX E: \\ LEVEL I DATA FORM}


U. S. Geological Survey

Bridge Field Data Collection and Processing Form

Qa/Qc Check by: EW

Date: $\mathbf{0 2 / 2 8 / 9 6}$

\section{A. General Location Descriptive}

1. Data collected by (First Initial, Full last name) R. HAMMOND

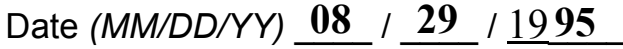

2. Highway District Number $\mathbf{0 7}$

County Caledonia (005)

Waterway (I - 6) Heath Brook

Route Number TH24

Mile marker $\mathbf{0}$

Town Groton (30550)

Road Name Seyon Pond Road

Hydrologic Unit Code: $\mathbf{0 1 0 8 0 1 0 2}$

3. Descriptive comments:

The bridge is located at the junction with Town Highway 27 and 1.5 miles from US Route 302.

\section{B. Bridge Deck Observations}

\section{Surface cover... $\quad$ LBUS $4 \quad$ RBUS $4 \quad$ LBDS $4 \quad$ RBDS 4 Overall 4}

(2b us,ds,lb,rb: 1- Urban; 2- Suburban; 3- Row crops; 4- Pasture; 5- Shrub- and brushland; 6- Forest; 7- Wetland)

5. Ambient water surface...US $\underline{2}$ UB $\underline{2}$ DS $\underline{1}$ (1-pool; 2- riffle)

6. Bridge structure type 1 (1- single span; 2- multiple span; 3- single arch; 4- multiple arch; 5-cylindrical culvert; 6- box culvert; or 7- other)
7. Bridge length $\mathbf{3 0 . 0}$
(feet)
Span length $\mathbf{2 7 . 0}$
(feet)
Bridge width 25.4 (feet)

\section{Road approach to bridge:}
8. LB 2 RB 1
( 0 even, 1- lower, 2- higher)
9. LB 2 RB $\underline{2}$
(1- Paved, 2- Not paved)

10. Embankment slope (run / rise in feet / foot):

US left

US right

\begin{tabular}{|c|c|c|c|}
\hline \multicolumn{2}{|c|}{ Protection } & \multirow{2}{*}{ 13.Erosion } & 14.Severity \\
\hline 11.Type & 12.Cond. & $\mathbf{0}$ & - \\
\hline $\mathbf{2}$ & $\mathbf{1}$ & $\mathbf{0}$ & - \\
$\mathbf{0}$ & - & $\mathbf{0}$ & - \\
\hline $\mathbf{2}$ & $\mathbf{1}$ & $\mathbf{0}$ & - \\
\hline $\mathbf{0}$ & - & $\mathbf{2}$ & $\mathbf{2}$ \\
\hline
\end{tabular}

Bank protection types: 0- none; 1- < 12 inches;

2- < 36 inches; $3-<48$ inches;

4- $<60$ inches; 5- wall / artificial levee

Bank protection conditions: 1- good; 2- slumped;

3- eroded; 4- failed

Erosion: 0 - none; 1- channel erosion; 2-

road wash; 3- both; 4- other

Erosion Severity: 0 - none; 1- slight; 2- moderate;

\section{Channel approach to bridge (BF):}

15. Angle of approach: $\mathbf{0}$

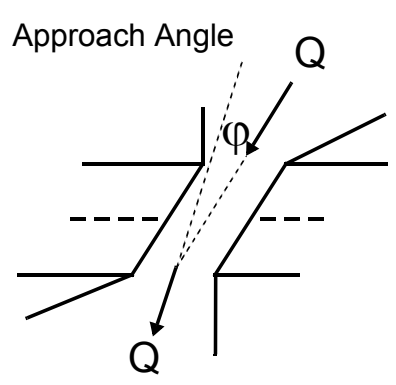

17. Channel impact zone 1 :

Where? $(L B, R B)$

Range? feet -

Channel impact zone 2:

Where? $(L B, R B)$

Range? - $\quad$ feet -

Impact Severity: 0- none to very slight; 1- Slight; 2- Moderate; 3- Severe (US, UB, DS) to -

, DS) to - feet -

16. Bridge skew: $\mathbf{3 0}$ Bridge Skew Angle

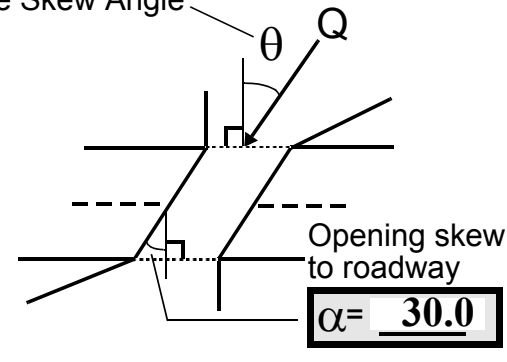

Exist? $\underline{\mathbf{N}}(\mathrm{Y}$ or $N)$

Severity -

(US, UB, DS) to -

Exist? - $\quad(Y$ or $N)$

Severity - 
18. Bridge Type: 1a

1a- Vertical abutments with wingwalls

1 b- Vertical abutments without wingwalls

2- Vertical abutments and wingwalls, sloping embankment Wingwalls parallel to abut. face

3- Spill through abutments

4- Sloping embankment, vertical wingwalls and abutments

Wingwall angle less than $90^{\circ}$.

19. Bridge Deck Comments (surface cover variations, measured bridge and span lengths, bridge type variations, approach overflow width, etc.)

\#7: The values are from VTAOT form. The measured values include: the US bridge span length=25.0 ft; the DS bridge span length $=\mathbf{2 6 . 0} \mathrm{ft}$; the bridge length $=30 \mathrm{ft}$; and the bridge width $25.4 \mathrm{ft}$.

\#18: The slope of USRWW terminates just below low chord elevation.

\section{Upstream Channel Assessment}

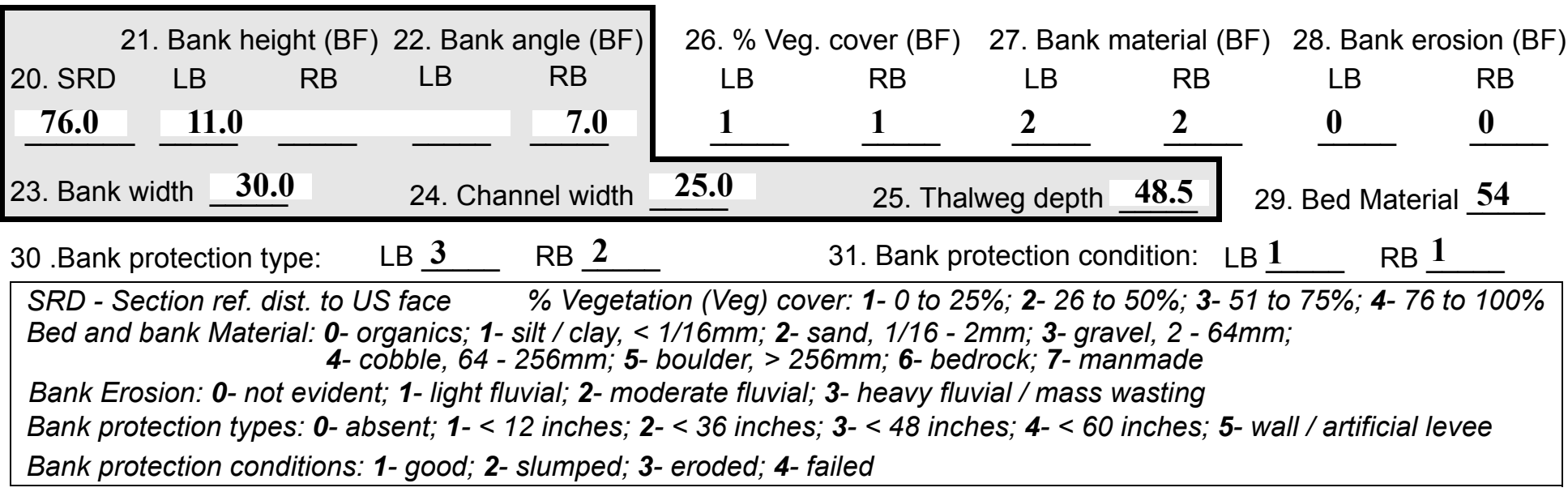

32. Comments (bank material variation, minor inflows, protection extent, etc.):

Protection extent: Protection extends along the right bank from $0 \mathrm{ft}$ to $80 \mathrm{ft}$ upstream. Protection along the left bank extends from $0 \mathrm{ft}$ to $90 \mathrm{ft}$ upstream. 
33.Point/Side bar present? $\mathbf{N}(Y$ or $N$. if $N$ type ctrl-n pb)34. Mid-bar distance: -

35. Mid-bar width: -

36. Point bar extent: feet (US, UB) to feet (US, UB, DS) positioned $\%$ LB to $\% \mathrm{RB}$

37. Material: -

38. Point or side bar comments (Circle Point or Side; Note additional bars, material variation, status, etc.):

There are no point bars upstream at this site.

39. Is a cut-bank present? $\underline{\mathbf{N}}$ (Y or if $\mathrm{N}$ type ctrl-n cb)

40. Where? (LB or $R B)$

41. Mid-bank distance: -

42. Cut bank extent: feet (US, UB) to feet (US, UB, DS)

43. Bank damage: ( 1- eroded and/or creep; 2- slip failure; 3- block failure)

44. Cut bank comments (eg. additional cut banks, protection condition, etc.):

There are no cut-banks upstream at this site.

\section{Is channel scour present? $\mathbf{N}$ ( $Y$ or if $N$ type ctrl-n cs)}

47. Scour dimensions: Length Width Depth : 46. Mid-scour distance: -

48. Scour comments (eg. additional scour areas, local scouring process, etc.):

There is no channel scour upstream at this site.

\section{Are there major confluences? $\mathbf{N}$}

51. Confluence 1: Distance Confluence 2: Distance 52. Enters on Enters on ( $Y$ or if $N$ type ctrl-n mc) 54. Confluence comments (eg. confluence name):

There are no major confluences upstream at this site.

\section{Under Bridge Channel Assessment}

55. Channel restraint (BF)? LB 2 (1- natural bank; 2- abutment; 3- artificial levee)

\begin{tabular}{|ccccc}
\multicolumn{2}{|c}{ 56. Height (BF) } & \multicolumn{3}{c}{57 Angle (BF) } \\
LB & RB & LB & RB \\
$\mathbf{1 7 . 0}$ & & & $\mathbf{1 . 5}$ & \\
\hline
\end{tabular}

58. Bank width (BF) -

59. Channel width -
61. Material (BF)

LB RB

$\underline{2} \quad \underline{7}$
62. Erosion (BF)

LB RB

$7 \quad 0$
(1- perennial; 2- ephemeral) (1-perennial; 2- ephemeral)
50. How many? -

53. Type-

Type $\% \mathrm{RB}$

Bed and bank Material: 0- organics; 1- silt / clay, < 1/16mm; 2- sand, 1/16 - 2mm; 3- gravel, 2 - 64mm; 4- cobble, 64 - 256mm; 5- boulder, > 256mm; 6- bedrock; 7- manmade

Bank Erosion: 0- not evident; 1- light fluvial; 2- moderate fluvial; 3- heavy fluvial / mass wasting

64. Comments (bank material variation, minor inflows, protection extent, etc.):

54

Channel scour exists under the bridge- refer to notes in downstream assessment. 
65. Debris and Ice Is there debris accumulation?

67. Debris Potential $\underline{1}$ ( 1- Low; 2- Moderate; 3- High)

69. Is there evidence of ice build-up? 1

70. Debris and Ice Comments:
(Yor $N)$ 66. Where? $\underline{Y}$

68. Capture Efficiency 2

(1- Upstream; 2- At bridge; 3-Both)

Ice Blockage Potential $\mathbf{N}$
(1- Low; 2- Moderate; 3- High)

(1-Low; 2- Moderate; 3- High)

\section{1}

\begin{tabular}{|l|c|c|c|c|c|c|c|c|}
\hline Abutments & $\begin{array}{c}\text { 71. Attack } \\
\angle \text { (BF) }\end{array}$ & $\begin{array}{c}72 \text {. Slope } \angle \\
\text { (Qmax) }\end{array}$ & $\begin{array}{c}\text { 73. Toe } \\
\text { loc. (BF) }\end{array}$ & $\begin{array}{c}\text { 74. Scour } \\
\text { Condition }\end{array}$ & $\begin{array}{c}\text { 75. Scour } \\
\text { depth }\end{array}$ & $\begin{array}{c}\text { 76. Exposure } \\
\text { depth }\end{array}$ & 77. Material & 78. Length \\
\hline LABUT & & $\mathbf{0}$ & $\mathbf{9 0}$ & $\mathbf{2}$ & $\mathbf{0}$ & - & - & $\mathbf{9 0 . 0}$ \\
\hline RABUT & $\mathbf{1}$ & $\mathbf{0}$ & $\mathbf{9 0}$ & & & $\mathbf{2}$ & $\mathbf{0}$ & $\mathbf{2 1 . 5}$ \\
\hline
\end{tabular}

Pushed: $L B$ or RB

Toe Location (Loc.): 0- even, 1- set back, 2- protrudes

Scour cond.: 0- not evident; 1- evident (comment); 2- footing exposed; 3-undermined footing; 4- piling exposed; 5- settled; 6- failed

Materials: 1- Concrete; 2- Stone masonry or drywall; 3- steel or metal; 4- wood

79. Abutment comments (eg. undermined penetration, unusual scour processes, debris, etc.):

80. Wingwalls:

Exist? Material? Scour Scour Exposure Angle? Length? Condition? depth? depth?

USLWW:

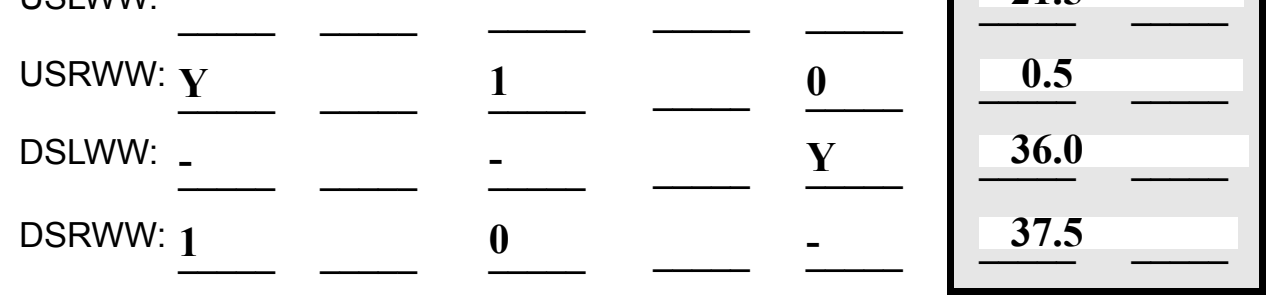

Wingwall materials: 1- Concrete; 2- Stone masonry or drywall; 3- steel or metal; 4- wood

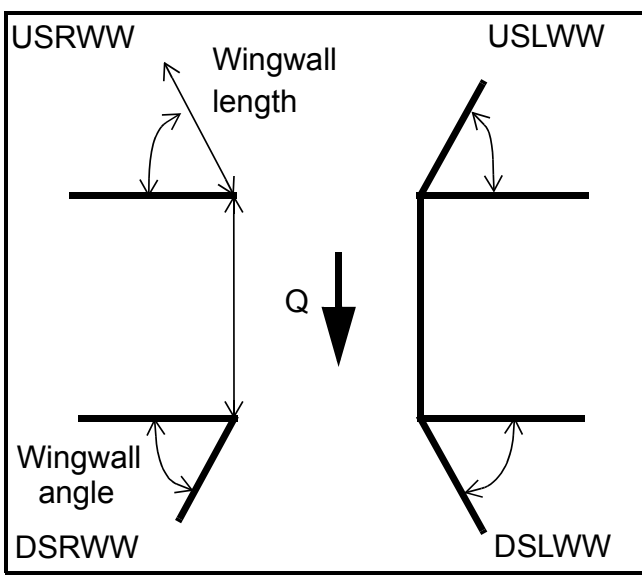

82. Bank / Bridge Protection:

\begin{tabular}{|l|l|l|l|l|l|l|l|c|}
\hline Location & USLWW & USRWW & LABUT & RABUT & LB & RB & DSLWW & DSRWW \\
\hline Type & - & $\mathbf{0}$ & $\mathbf{Y}$ & - & $\mathbf{1}$ & $\mathbf{1}$ & $\mathbf{1}$ & $\mathbf{1}$ \\
\hline Condition & $\mathbf{Y}$ & - & $\mathbf{1}$ & - & $\mathbf{1}$ & $\mathbf{1}$ & $\mathbf{1}$ & $\mathbf{1}$ \\
\hline Extent & $\mathbf{1}$ & - & $\mathbf{0}$ & $\mathbf{2}$ & $\mathbf{2}$ & $\mathbf{2}$ & $\mathbf{2}$ & - \\
\hline
\end{tabular}

Bank / Bridge protection types: 0- absent; 1- < 12 inches; 2- < 36 inches; 3- < 48 inches; 4- < 60 inches; 
83. Wingwall and protection comments (eg. undermined penetration, unusual scour processes, etc.):

-
-
-
-
-
2
1
1
2
1
1

\section{Piers:}

84. Are there piers? _ _ (Y or if $N$ type ctrl-n pr)

\begin{tabular}{|l|r|l|l|l|l|l|l|}
\hline \multirow{2}{*}{$\begin{array}{l}85 . \\
\text { Pier no. }\end{array}$} & \multicolumn{3}{|c|}{ width (w) feet } & \multicolumn{5}{c|}{ elevation (e) feet } \\
\cline { 2 - 8 } & w1 & w2 & w3 & e@w1 & e@w2 & e@w3 \\
\hline Pier 1 & & & & $\mathbf{2 0 . 0}$ & $\mathbf{2 3 . 0}$ & $\mathbf{6 0 . 0}$ \\
\hline Pier 2 & $\mathbf{9 . 0}$ & & $\mathbf{5 . 0}$ & $\mathbf{1 0 . 0}$ & $\mathbf{1 6 . 5}$ & $\mathbf{1 4 . 0}$ \\
\hline Pier 3 & - & - & - & - & - & - \\
\hline Pier 4 & - & - & - & - & - & - \\
-
\end{tabular}

\begin{tabular}{|c|c|c|c|c|}
\hline Level 1 Pier Descr. & 1 & 2 & 3 & 4 \\
\hline 86. Location (BF) & & - & - & - \\
\hline 87. Type & & - & - & - \\
\hline 88. Material & & - & - & - \\
\hline 89. Shape & & - & - & - \\
\hline 90. Inclined? & & - & - & - \\
\hline 91. Attack $\angle(\mathrm{BF})$ & & - & - & - \\
\hline 92. Pushed & & - & - & - \\
\hline 93. Length (feet) & - & - & - & - \\
\hline 94. \# of piles & & - & - & - \\
\hline 95. Cross-members & & - & - & - \\
\hline 96. Scour Condition & & - & - & - \\
\hline 97. Scour depth & $\mathbf{N}$ & - & - & - \\
\hline 98. Exposure depth & - & - & - & - \\
\hline
\end{tabular}

LFP, LTB, LB, MCL, MCM, MCR, RB, RTB, RFP

1- Solid pier, 2- column, 3- bent

1-Wood; 2- concrete; 3- metal; 4- stone

1- Round; 2- Square; 3- Pointed

Y-yes; $N-$ no

$L B$ or $R B$

0- none; 1- laterals; 2- diagonals; 3- both

0- not evident; 1- evident (comment);

2- footing exposed; 3- piling exposed;

4- undermined footing; 5- settled; 6- failed 
99. Pier comments (eg. undermined penetration, protection and protection extent, unusual scour processes, etc.):

-
-
-
-
-
-
-
-
-
-

100.

\section{E. Downstream Channel Assessment}

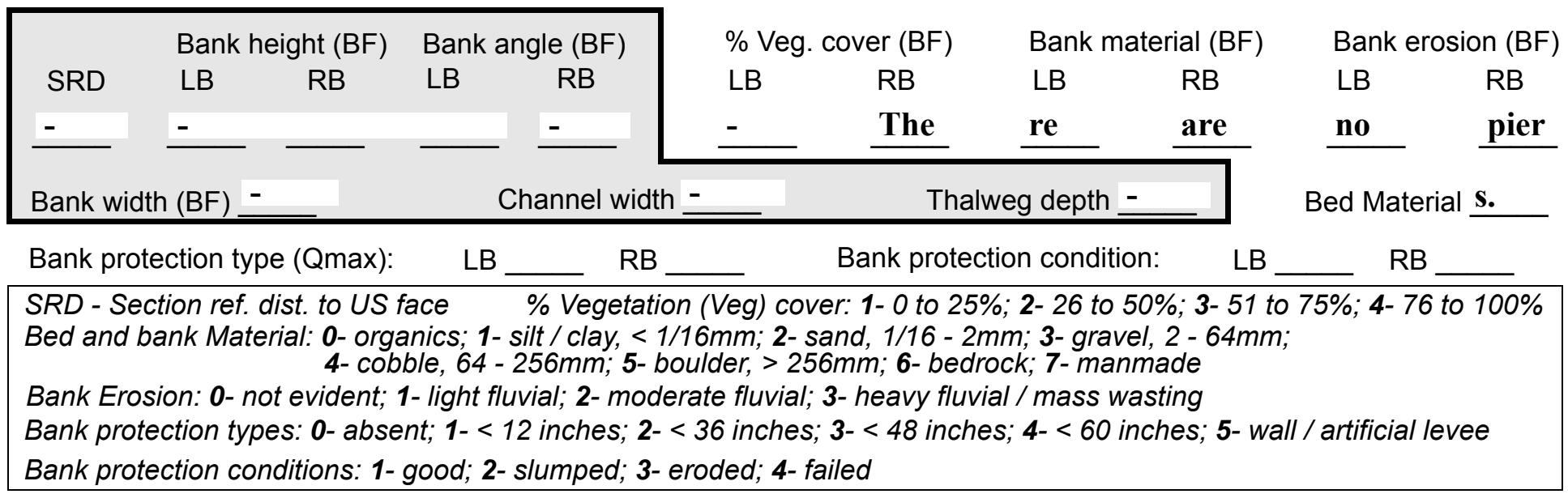

Comments (eg. bank material variation, minor inflows, protection extent, etc.):

$\mathbf{2}$
$\mathbf{2}$
$\mathbf{5}$
7
$\mathbf{0}$
$\mathbf{0}$
$\mathbf{5 4 3}$
$\mathbf{2}$
$\mathbf{2}$
$\mathbf{1}$

101. Is a drop structure present? 1 (Y or $N$, if $N$ type ctrl-n ds) 102. Distance: _ _ feet

103. Drop: -_ feet 104. Structure material: He (1- steel sheet pile; 2- wood pile; 3- concrete; 4- other) 105. Drop structure comments (eg. downstream scour depth):

ath Brook enters the right bank of the South Branch of the Wells River at the downstream bridge face. 
106. Point/Side bar present? (Y or $N$. if $N$ type ctrl-n pb)Mid-bar distance:

Mid-bar width:

Point bar extent: feet

(US, UB, DS) to feet (US, UB, DS) positioned $\%$ LB to $\%$ RB

Material: $\mathbf{N}$

Point or side bar comments (Circle Point or Side; note additional bars, material variation, status, etc.):

There is no drop structure at this site.

Is a cut-bank present? (Y or if $N$ type ctrl- $n$ cb) Where? (LB or $R B)$

Mid-bank distance: Cut bank extent: $\underline{\mathbf{N}}$ feet - $(U S, U B, D S)$ to - feet -

Bank damage: - _ (1- eroded and/or creep; 2- slip failure; 3- block failure)

Cut bank comments (eg. additional cut banks, protection condition, etc.):

$-$

$-$

$-$

Is channel scour present? __ (Y or if N type ctrl-n cs) Mid-scour distance: Ther

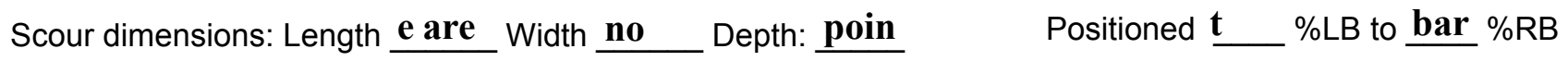

Scour comments (eg. additional scour areas, local scouring process, etc.):

s downstream at this site.

Are there major confluences? $\mathbf{N}$ ( $Y$ or if $N$ type ctrl-n $m c)$

Confluence 1: Distance -

Confluence 2: Distance -

Enters on (LB or $R B)$

Enters on (LB or $R B)$

Confluence comments (eg. confluence name):

There are no cut-banks downstream at this site.
How many? -

Type (1-perennial; 2- ephemeral)

Type = (1- perennial; 2- ephemeral)

\section{F. Geomorphic Channel Assessment}

107. Stage of reach evolution
1- Constructed

2- Stable

3- Aggraded

4- Degraded

5- Laterally unstable

6- Vertically and laterally unstable 
108. Evolution comments (Channel evolution not considering bridge effects; See HEC-20, Figure 1 for geomorphic descriptors):

$\mathbf{Y}$

25

65

20

3

0

80

Scour hole exists from 15 feet UB to 50 feet DS.

Y 


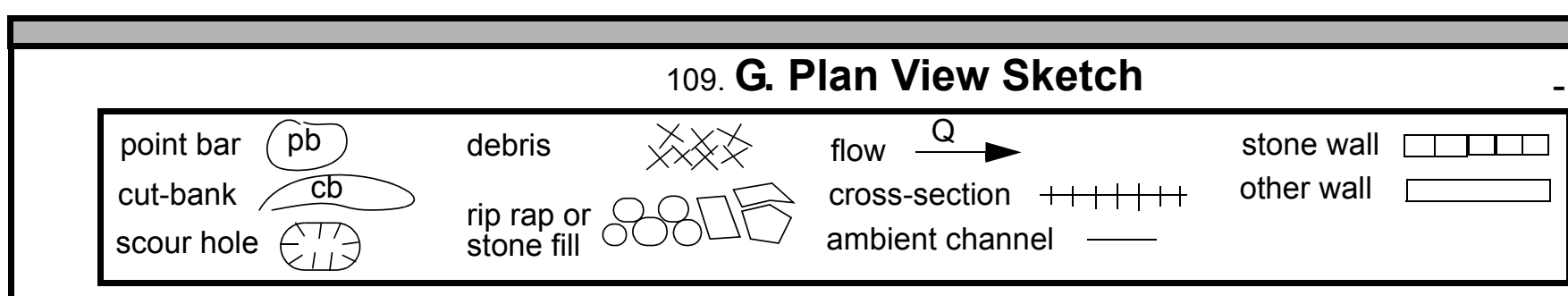

cut-bank $\mathrm{cb}$

scour hole $\mathrm{EI}$ rip rap or stone fill $000 \mathrm{~L}$ cross-section $+1+1+1$ ambient channe 
APPENDIX F:

SCOUR COMPUTATIONS 
SCOUR COMPUTATIONS

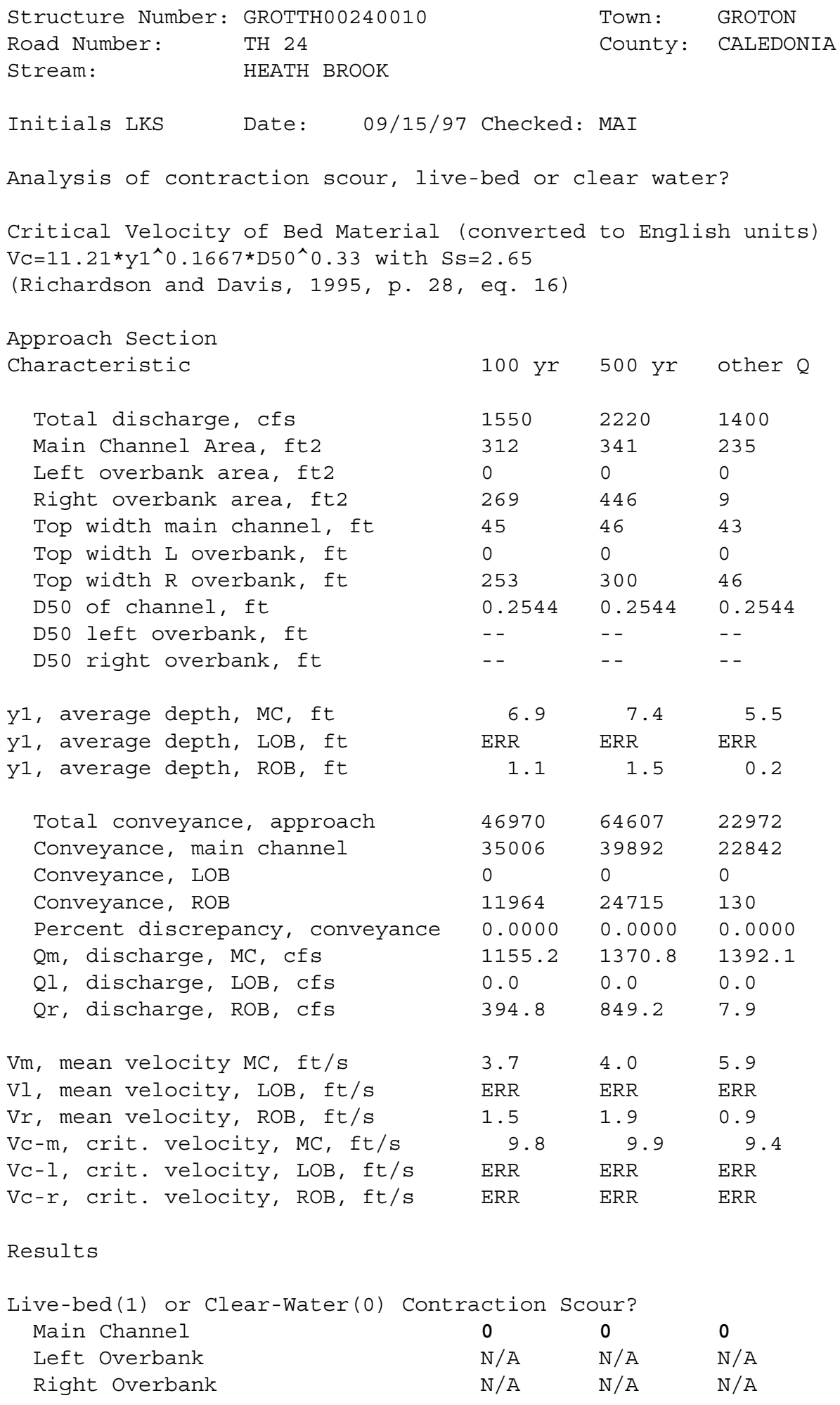


Clear water Contraction Scour in MAIN CHANNEL

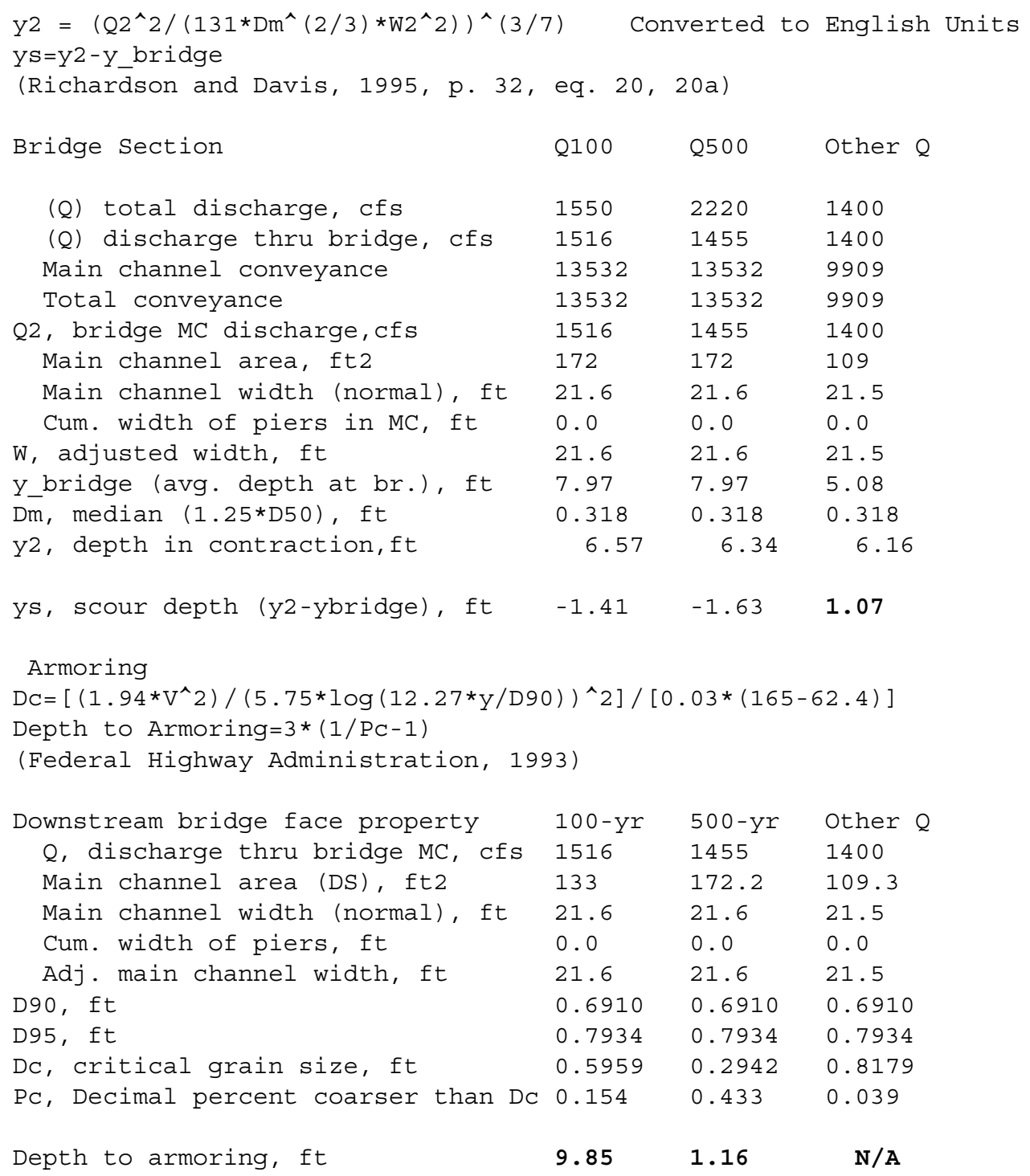




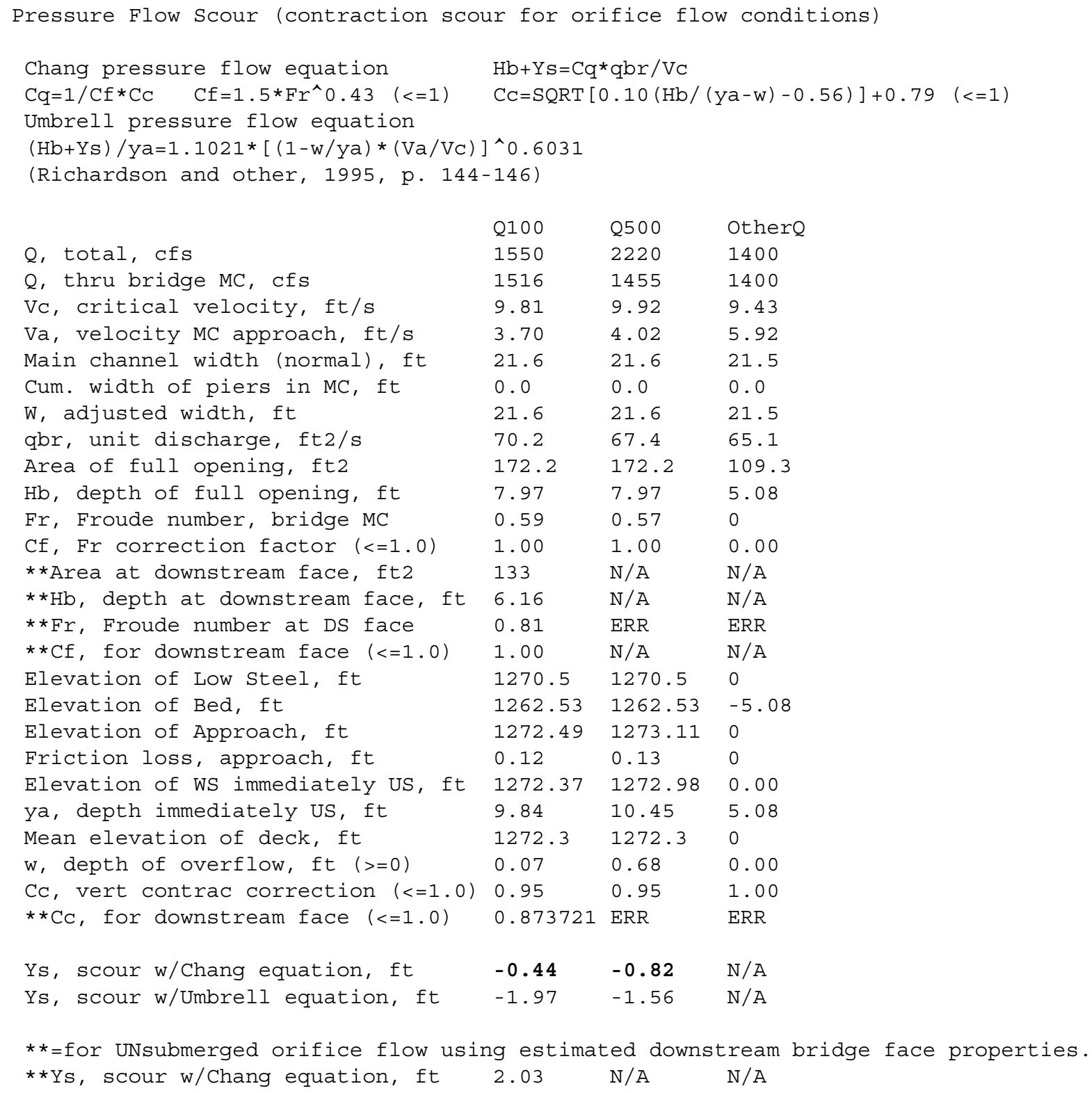


**Ys, scour w/Umbrell equation, ft $-0.16 \quad \mathrm{~N} / \mathrm{A} \quad \mathrm{ERR}$

In UNsubmerged orifice flow, an adjusted scour depth using the Laursen equation results and the estimated downstream bridge face properties can also be computed (ys=y2-ybridgeDs)

$\begin{array}{lllll}\text { y2, from Laursen's equation, ft } & 6.57 & 6.34 & 6.16\end{array}$

WSEL at downstream face, ft $1268.66 \quad--$

Depth at downstream face, ft $6.16 \quad \mathrm{~N} / \mathrm{A} \quad \mathrm{N} / \mathrm{A}$

Ys, depth of scour (Laursen), ft 0.41 N/A N/A

Abutment scour

Froehlich's Abutment Scour

$\mathrm{Ys} / \mathrm{Y} 1=2.27 * \mathrm{~K} 1 * \mathrm{~K} 2 *\left(\mathrm{a}^{\prime} / \mathrm{Y} 1\right)^{\wedge} 0.43 * \mathrm{Fr} 1^{\wedge} 0.61+1$

(Richardson and Davis, 1995, p. 48, eq. 28)

\begin{tabular}{|c|c|c|c|c|c|c|}
\hline \multirow[b]{2}{*}{ Characteristic } & \multicolumn{2}{|c|}{ Left Abutment } & \multicolumn{4}{|c|}{ Right Abutment } \\
\hline & \multicolumn{3}{|c|}{100 yr Q 500 yr Q Other Q } & \multicolumn{3}{|c|}{$100 \mathrm{yr} Q 500 \mathrm{yr} Q$ Other Q } \\
\hline (Qt), total discharge, cfs & 1550 & 2220 & 1400 & 1550 & 2220 & 1400 \\
\hline a', abut.length blocking flow, ft & 11.2 & 12.1 & 8.5 & 265.5 & 312.8 & 59.2 \\
\hline Ae, area of blocked flow ft 2 & 40.69 & 44.98 & 23.62 & 328.92 & 324.45 & 56 \\
\hline Qe, discharge blocked abut., cfs & 90 & -- & 81.67 & -- & -- & 210 \\
\hline (If using Qtotal_overbank to ok & in $V e$, & ave Qe & ank an & nter Ve & id Fr m & \\
\hline $\mathrm{Ve},(\mathrm{Qe} / \mathrm{Ae}), \mathrm{ft} / \mathrm{s}$ & 2.21 & 2.50 & 3.46 & 1.79 & 2.12 & 3.75 \\
\hline ya, depth of $\mathrm{f} / \mathrm{p}$ flow, ft & 3.63 & 3.72 & 2.78 & 1.24 & 1.04 & 0.95 \\
\hline --Coeff., K1, for abut. type (1.0, & verti.; & $.82, \mathrm{ve}$ & i. w/ & gwall; & 5, spi & chru) \\
\hline $\mathrm{K} 1$ & 0.82 & 0.82 & 0.82 & 0.82 & 0.82 & 0.82 \\
\hline --Angle (theta) of embankment $(<90$ & if abut & points & ; $>90$ & abut. pc & its US) & \\
\hline theta & 60 & 60 & 60 & 120 & 120 & 120 \\
\hline $\mathrm{K} 2$ & 0.95 & 0.95 & 0.95 & 1.04 & 1.04 & 1.04 \\
\hline Fr, froude number $f / p$ flow & 0.204 & 0.221 & 0.366 & 0.279 & 0.289 & 0.679 \\
\hline ys, scour depth, ft & 7.59 & 8.06 & 7.07 & 12.29 & 11.98 & 9.50 \\
\hline
\end{tabular}

HIRE equation ( $a^{\prime} /$ ya $\left.>25\right)$

$\mathrm{ys}=4 * \mathrm{Fr}^{\wedge} 0.33 * \mathrm{Y} 1 * \mathrm{~K} / 0.55$

(Richardson and Davis, 1995, p. 49, eq. 29) 


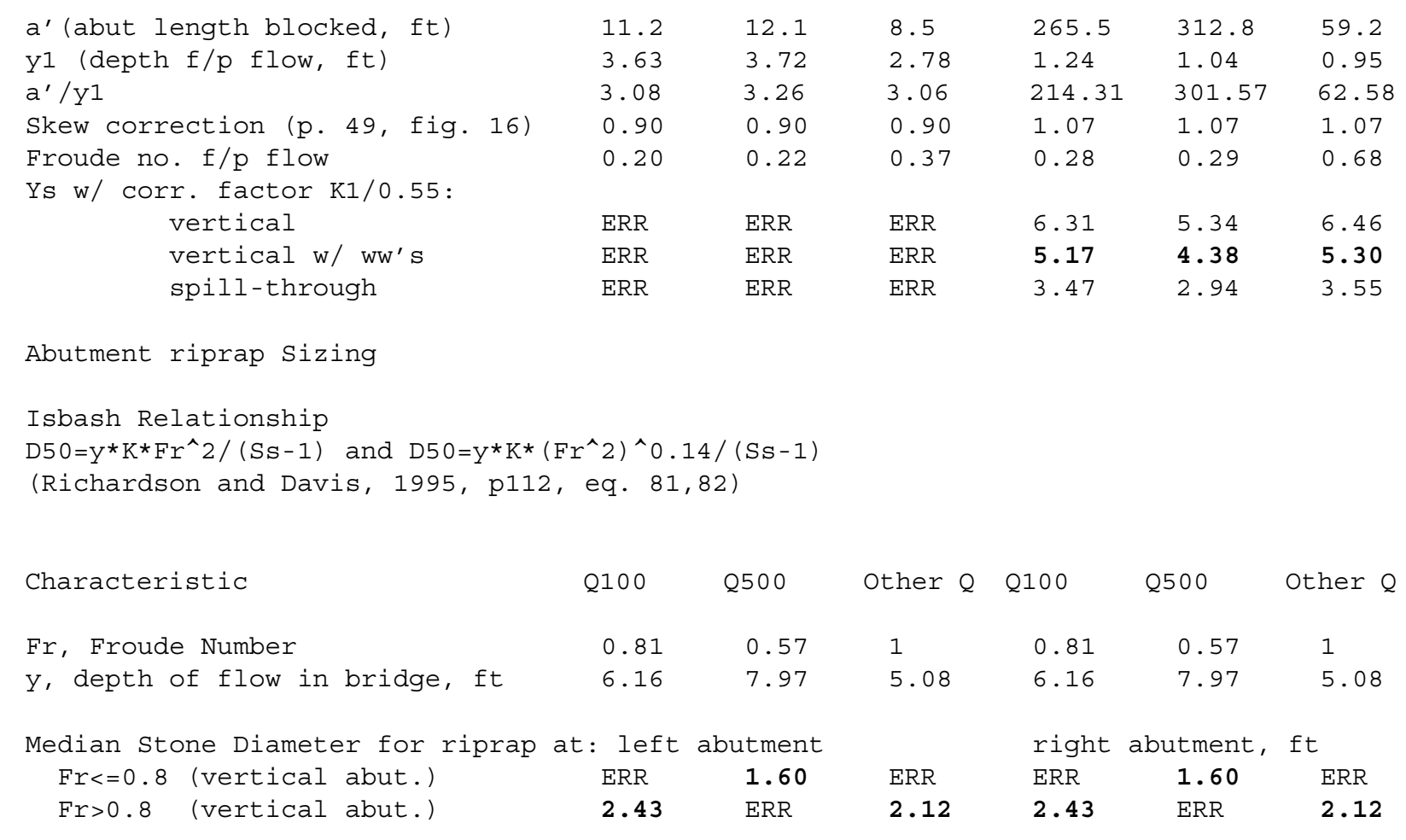

